\title{
The external effects of offshoring on job security in SMEs
}

\author{
Zouheir El-Sahli $\mathbb{D} \cdot$ Joakim Gullstrand • \\ Karin Olofsdotter
}

Accepted: 13 October 2021 / Published online: 7 January 2022

(C) The Author(s), under exclusive licence to Springer Science+Business Media, LLC, part of Springer Nature 2021

\begin{abstract}
We investigate the effects of offshoring on job security using matched employer-employee data from Sweden. Between 1997 and 2011, the share of offshoring firms fell from around 25 to $22 \%$ while offshoring per worker within offshoring firms almost doubled. We use this variation to contribute to the literature by examining the effects of the neighboring firms' offshoring (external offshoring) on job separation in small and medium-sized enterprises (SMEs). Our results suggest that external offshoring has a significant impact on job security in SMEs that do not offshore themselves. In addition, having a university degree, being young, and being new to the job reduce the risk of a job exit due to increased external offshoring. This result is indicative of a Schumpeterian jobrestructuring effect where old jobs are replaced by newer ones. Finally, the increased risk of a job exit in SMEs suggests a higher vulnerability of these firms
\end{abstract}

Z. El-Sahli $(\bowtie)$

Department of Finance and Economics, College of Business and Economics, Qatar University, PO

Box 2713, Doha, Qatar

e-mail: zelsahli@qu.edu.qa

J. Gullstrand · K. Olofsdotter

Department of Economics, Lund University, Tycho Brahes

väg 1, Lund, Sweden

e-mail: joakim.gullstrand@nek.lu.se

K. Olofsdotter

e-mail: karin.olofsdotter@nek.lu.se to local shocks due to offshoring activities in larger neighboring firms.

Plain English Summary Offshoring leads to higher job exits in small and medium-sized enterprises (SMEs) that do not offshore themselves, as per new evidence from manufacturing firms in Sweden. This effect is highest for less educated and older workers. Manufacturers are ever more involved in fragmented supply chains where they supply intermediate inputs to one another. This suggests that any decision made by one manufacturer to offshore (replace a local supplier with a foreign one) may have negative effects on the workers of other firms. SMEs may be more vulnerable to offshoring because they tend to be more local in their activities, although they may not offshore themselves. This study uses a data set from Sweden to explore the effects of offshoring on the job security of workers in small and medium-size enterprises (SMEs). We find that offshoring activities within Sweden lead to higher job exits in SMEs that do not offshore themselves. This effect is highest for low skill (less educated) and older workers. Policy makers should be aware of the vulnerability of SMEs to offshoring activities of other often-larger firms through channels related to supply chains.

Keywords Offshoring · Heterogeneous firms · Job security · Globalization · Small and medium-sized enterprises $\cdot$ Swedish manufacturing 


\section{JEL classification $\quad \mathrm{F} 16 \cdot \mathrm{F} 66 \cdot \mathrm{J} 64 \cdot \mathrm{L} 26$}

\section{Introduction}

Offshoring remains a controversial issue in most high-income countries. Media frequently reports on how offshoring, i.e., shifting the location of manufacturing and service activities abroad, may hurt workers and lead to job insecurity, and the Trump presidential campaign explicitly ran on a platform that stressed the need to "bring jobs back to America from abroad." A balanced assessment of offshoring, however, should take into account how cost savings could have beneficial effects on workers and firms, and how linkages across firms and industries affect labor markets. The fragmentation of supply chains and the emergence of global value chains suggest that the effects of offshoring, or other trade shocks, will have economy wide effects due to buyer-seller linkages and changes in demand that go beyond the industry of the offshoring firm. ${ }^{1}$ For the purpose of this paper, it is important to realize that small and medium-sized enterprises (SMEs) are highly integrated in global value chains. ${ }^{2}$ While some of these firms are offshoring firms, many SMEs are only indirectly involved as suppliers to larger offshoring firms. There are also reasons to believe that SMEs that do not offshore themselves are more vulnerable to other firms' offshoring. As far as we know, there are not many studies on the employment effects of offshoring that focus on SMEs and take the fragmentation of the supply chain perspective. Hence, in this study, we investigate the effects of offshoring on job separations in Swedish manufacturing firms, with a particular emphasis on workers in SMEs that may not be offshoring themselves but are affected by the offshoring of often-larger firms.

There are several aspects to consider when it comes to the effects of offshoring on domestic workers. First, there are relocation and scale effects. The relocation effect occurs when offshoring results in

\footnotetext{
${ }^{1}$ The COVID-19 crisis also brought to light some problems with global value chains - the hallmark of offshoring - in the face of extreme events.

${ }^{2}$ In 2011, Swedish firms with less than 100 employees accounted for almost $65 \%$ of all jobs associated with global value chain participation (Growth Analysis, 2014).
}

moving abroad activities or tasks that have previously been performed domestically and thereby affecting the jobs associated with these very tasks negatively. The scale effect, on the other hand, arises when offshoring increases the productivity of the firm due to increased specialization, enabling the firm to expand and increase the demand for workers (Grossman \& Rossi-Hansberg, 2008). Second, these effects could be both direct and indirect. The direct effect refers to how workers are affected by offshoring activities of the firm in which they are employed. This effect, by far, has gained the most attention by researchers. However, a worker may also be affected indirectly by offshoring carried out by firms other than the worker's own. The most straightforward way to see this, following the example in Merlevede and Michel (2020), is as follows. Consider two firms, a downstream firm $\mathrm{C}$ (customer) and an upstream firm A. The two firms are linked together in a buyer-seller relationship in the value chain of a given industry. Downstream firm $\mathrm{C}$ may choose to offshore the intermediates that it previously sourced from firm A to a foreign upstream supplier firm F. This is a negative demand shock for firm A, often a small or medium-sized firm, and the workers of this supplier are expected to be disadvantaged. There might also be a scale effect similar to the one described above if the offshoring firm $\mathrm{C}$ starts to grow due to efficiency gains, absorbing some of the negative employment effects for workers in other firms, but the importance of this effect seems highly uncertain. Up to now, the empirical literature on offshoring has largely ignored these possible indirect effects of offshoring. Two notable exceptions are Egger and Egger (2005) and the more recent contribution by Merlevede and Michel (2020). Egger and Egger (2005) show that considering industrial interdependence is important to understand the wider effects of international outsourcing on labor markets. The effects of this industrial interdependence occur through (i) linkages (intermediate goods delivered) between industries and (ii) factor flows (workers) across industries. Merlevede and Michel (2020) also highlight the importance of buyer-seller relationships in understanding the labor effects of "downstream" offshoring. They use input-output tables to measure offshoring faced by the (upstream) firm as the share of foreign sourcing of the goods produced by the firm in a downstream industry. Both studies find support 
for indirect negative effects of offshoring on employment in upstream firms.

We use matched employer-employee data for Sweden in order to investigate the effects of offshoring on the individual worker. ${ }^{3}$ As we are interested in the indirect effects that may capture linkages (both direct and indirect) and, in particular, the effects on workers in SMEs that do not offshore on their own, we focus on local markets. In doing so, we rely on evidence in the literature (which we review below) that highlights the significance of proximity in local buyer-seller relationships, as well as the fact that SMEs are more local by nature, as we also show below. Since SMEs tend to be more local, this implies that they may be disproportionately affected by offshoring decisions made by other firms, even though SMEs are less likely to offshore themselves. Hence, we focus on the worker effects of offshoring conducted by other firms on SMEs, which we call external offshoring. To capture the importance of local markets, we create a measure of external offshoring that is based on the offshoring of all firms in the economy, but giving more weight to offshoring made in the proximity. Our measure of offshoring follows the customary definition of offshoring in the literature as the sourcing of intermediate goods from abroad, but we differ in that the firm is exposed to the collective offshoring of all offshoring firms, highlighting the importance of linkages across industries.

It should be noted that while we do not have data on direct buyer-seller linkages, our proxy of external offshoring in the local market could only be indicative of such a relationship. In fact, our measure will capture indirect linkages between firms as well. For example, assume that the SMEs in a local market A do not supply the big firm in market A, but firm 1 in another local market B. At the same time, firm 1 is the main supplier to the big firm in market A. If firm 1 should experience a shock that drives the firm out of the market, this will be a negative demand shock for the SMEs in market A, leading to job separations. As the big firm in market A has lost its supplier, the

\footnotetext{
${ }^{3}$ This paper is also one of very few papers to use matched employer-employee data to study the effects of offshoring on job separation, an exception being Nilsson Hakkala and Huttunen (2016). This paper, however, only studies the direct effects.
}

firm sources its input from abroad instead. Thus, we see increased offshoring together with increased job separations in market A. However, this is not due to a direct linkage between the big firm and the SMEs, but a demand shock stemming from another local market. Hence, our approach will account for more complex scenarios in as much as a specific negative shock to a local firm will lead to a change in offshoring by an offshoring firm.

The literature has highlighted the significance of local markets and proximity even in countries that depend largely on international trade. Hillberry and Hummels (2008) emphasize the importance of geographical frictions for domestic trade and estimate that trade within US 5-digit zip codes is three times larger when compared to shipments outside the zip code. Bernard et al. (2019) underscore the significance of proximity when it comes to buyer-supplier networks, showing that the median distance between Japanese buyers and suppliers is no more than $30 \mathrm{~km}$. Other notable studies that have demonstrated the local nature of markets include Bennett et al. (2000), Hummels and Schaur (2013), Keller and Yeaple (2013), Wrona (2015), Furusawa et al. (2015), and Arnarson and Gullstrand (2016). Figure 1 supports these findings in a Swedish context. The figure draws on a survey conducted by Gullstrand (2017) and shows the share of sales to the local market for Swedish micro, small, and medium-sized firms. We observe that around $80 \%$ and $70 \%$ of the sales of micro and small firms, respectively, are made in close proximity (within the same municipality or county). The local market becomes less important for mediumsized firms but remains around 50\%. ${ }^{4}$ The figure also reveals that local markets are not only about reaching consumers as the share of sales to the local market is even higher for firms producing parts and inputs for other firms. Finally, Fig. 1 suggests an important issue that we are the first to bring to light: if smaller firms are more dependent on the local market, we would expect that workers in these firms be (more) affected by offshoring performed by global firms in their proximity.

In our analysis, we focus on workers in Swedish manufacturing SMEs for the period 2005-2011

\footnotetext{
4 That smaller firms are more dependent on local markets is also found in, e.g., Bernard et al. (2019).
} 
Fig. 1 Share of sales to local market by firm size and type. Sale shares are population-weighted averages defined by the location of the firm. The figure is based on a survey of small and medium-sized firms described in Gullstrand (2017). In the survey, a firm's local market is defined by the same municipality or county as the firm. Micro-firms are defined as having less than 10 employees, small firms between 10 and 49 , and medium-sized firms between 50 and 249 .

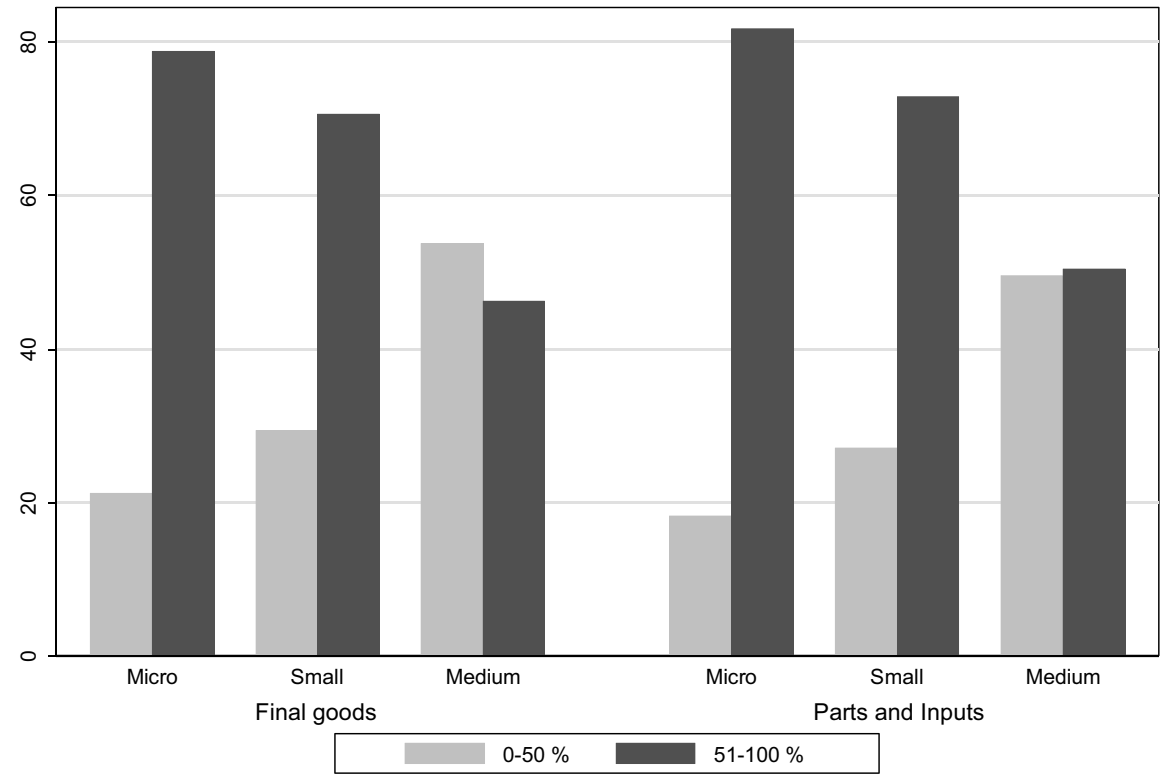

(although we use information from 1997 to define job spells), and we assess the effects of external offshoring on job separations (i.e., the likelihood of a job spell ending) through a discrete duration model. We make use of plant location in small spatial units to estimate the external effects of offshoring since it allows us to explore possible linkages in the same and surrounding spatial units. The use of detailed employer-employee data may however lead to endogeneity problems if offshoring activity is influenced by several underlying changes that also have an impact on the individual's job security (see Hummels et al., 2018). For example, internal offshoring may be affected by investments in new technology or products, while external offshoring could be influenced by changes in the mix of producers in the proximity of the firm. To deal with this, we construct a firm-specific instrument, which relies on the variation of world export supply as exogenous shocks for the firm's imports. This instrument will be described in further detail below (see Sect. 2.5).

The paper follows a growing body of literature that uses micro-level data to study the offshoring decisions of firms and their labor market outcomes. The vast majority of these studies focus on average wage adjustments that tend to have a long-run scope (see, for example, Amiti \& Davis, 2013; Hummels et al., 2014). Instead, we investigate the short-run adjustment costs to incumbent workers following offshoring decisions.
As argued by Davidson and Matusz (2011), short-run adjustment costs in terms of employment effects may be large both at the individual and at the aggregate level. There are only a few studies that have analyzed the effects of offshoring at the worker level as we do (see Egger et al., 2007; Geishecker, 2012; Munch, 2010; Görg \& Görlich, 2015). The advantage with using worker-level data is that important characteristics for workers' job security can be controlled. The previous studies, however, measure offshoring at the industry level and, therefore, do not separate between internal and external effects. We, on the other hand, can distinguish between the two types of offshoring as we link the workers to both firm-level information on offshoring, and the offshoring activities of other firms in the proximity of the workers' establishments.

We believe Sweden to be a good case for studying employment effects of structural adjustment from trade. Even though the Swedish labor market is considered to have low flexibility, this inflexibility is mainly on the wage setting side and not the employment side. ${ }^{5}$ As labor conditions and agreements are

\footnotetext{
$\overline{5}$ Botero et al. (2004) rank Sweden very high when it comes to overall labor market regulation. This is in sharp contrast with Sweden's southern neighbor Denmark, which is considered to have one of the most flexible labor markets in the world. As argued in Hummels et al., (2014, p. 1601), this flexibility is seen on both wage formation and employment protection.
} 
mostly determined through centralized negotiations between labor unions and employer organizations, the degree of individual wage setting is relatively low. This is also reflected in a very compressed wage structure. ${ }^{6}$ On the other hand, the labor market is much more flexible when it comes to employment. Since wages are decided collectively, adjustments in the labor market tend to occur through a reallocation of labor between firms, typically from less productive to more productive one. ${ }^{7}$ The room for collective dismissals in the form of plant closures and mass-layoffs is relatively large, and Sweden is, in this respect, among the more flexible countries within the OECD. ${ }^{8}$ In addition, Sweden is one of the least restrictive countries (ranked 29th) when it comes to the use of fixed-term and temporary work contracts (OECD, 2013).

There is a large amount of literature on the labor effects of offshoring. Traditionally, this literature has used aggregated industry-level data to estimate how offshoring affects wages and inequality. The main finding from these studies was that offshoring increases skilled labor's share of the wage bill in both the offshoring as well as the destination countries (see, e.g., Feenstra \& Hanson, 1997, 1999; Hsieh \& Woo, 2005). More recent work has employed firmlevel data to deal with endogeneity problems. The results from these studies are mixed. Castellani et al. (2008) use data on Italian firms and find that outward foreign direct investment (FDI) has no impact on skill composition, except for FDI towards Central and Eastern European countries. On the other hand, Becker et al. (2013) show that outward FDI increases the skill intensity of German firms. From the studies that address endogeneity problems at the firm level, such as Amiti and Davis (2011) and Mion and Zhu (2013), the evidence lends support to offshoring having a positive impact on the demand and wages of skilled workers in the offshoring firms. Andersson et al., $(2016,2017)$ are among the few studies that

\footnotetext{
${ }^{6}$ Comparing the top and bottom wage deciles, Sweden comes last among 22 OECD countries as the country with the lowest wage inequality (OECD, 2015).

7 Svalund et al. (2013) call this "external flexibility," relating to the Swedish Rehn-Meidner approach developed in the 1940s and 1950s.

8 The OECD ranked Sweden 7th in 2013 (out of 34) for restrictiveness in individual dismissals, but 26th for restrictiveness in collective dismissals.
}

provide evidence for Sweden. Using firm-level data for the period 1997-2002, they distinguish between service and material offshoring and find that the positive effect of offshoring on the relative demand for high-skilled workers within the firm is restricted to service offshoring, while no significant effect is found for material offshoring. ${ }^{9}$

Fewer studies have investigated the effects of offshoring on job separation and unemployment. One reason for this is the long-run perspective and fullemployment conditions underlying traditional trade theory. The papers that study employment spells have mostly used aggregated industry-level offshoring data. Egger et al. (2007), Geishecker (2012), Munch (2010), and Görg and Görlich (2015) all belong to this much smaller literature. The overall conclusion from these studies is that offshoring increases the probability of job separation. Hence, as argued in Geishecker (2012), offshoring may increase the insecurity of employees, and both Munch (2010) and Görg and Görlich (2015) find that this effect is asymmetric. The only paper using firm-level data on offshoring is Nilsson Hakkala and Huttunen (2016), whose results are in line with previous findings in that offshoring seems to increase the risk of job loss for all workers but, in particular, for workers in production occupations.

Our paper also relates to studies on the long-run effects of job displacements as well as to studies focusing on the local impact of trade shocks. This area of research finds that job displacements can have long-term effects on workers and that earning losses may be substantial (see, e.g., for the USA, Jacobson et al., 1993 and Couch \& Placzek, 2010; for Sweden, Eliason and Storrie, 2006; and for Norway, Huttunen et al., 2011). Hummels et al. (2014) use matched worker-firm data for Denmark and show that the negative effect of displacement due to offshoring on longterm earnings are significantly higher when compared with displacement due to other factors. In addition, low-skilled workers and workers with routine jobs face larger wage drops when exposed to offshoring. ${ }^{10}$

\footnotetext{
9 Andersson et al. (2016) also show that the positive effect of offshoring on the demand for high-skilled workers are due to service offshoring to middle-income countries.

${ }^{10}$ Using Swedish data, Nilsson Hakkala et al. (2014) also find that a firm's cost share of non-routine jobs increases as the firm become multinational. See also Martins and Opromolla (2009).
} 
Similar effects are found in Autor et al. (2014), who study the impact of import competition from China on the earnings and employment of US workers. Specifically, they find that workers exposed to trade shocks have lower earnings, and low-wage workers are more severely hurt. Looking at how workers adjust to import competition, they also find that the geographical mobility of workers is not an important adjustment mechanism, suggesting the local nature of labor markets (see also Autor et al., 2013). Our finding that increased exposure to external offshoring increases job insecurity supports the importance of local adjustments in Autor et al., (2013, 2014), but also the finding of local multipliers in Moretti (2010) and the transmission of shocks between sectors in Acemoglu et al. (2012).

This paper proceeds as follows. Section 2 describes the data, sample construction, measures of offshoring, and the use of instruments, as well as specifying the empirical strategy. Section 3 provides the results and various robustness checks. Section 4 concludes.

\section{Data, variables, and empirical approach}

The data originates from Statistics Sweden (SCB) and consists of merged information from two major databases with information on all individuals, plants, and firms in Sweden. First, LISA(longitudinal integration database for health insurance and labor market studies) database includes a large set of socio-economic variables for every individual in Sweden (e.g., income, occupation, education, birthdate, marital status) and provides information on the place of work (plant and firm) where the individual is employed. Secondly, the FEK (Structural Business Statistics) database includes detailed information on the number of employees, industry, and spatial location of all firms and their subordinate plants, as well as firmlevel information about sales, assets, investments, and trade (imports and exports at the 8-digit product level for each destination). With the help of this data, we construct a matched employee-employer database covering all manufacturing firms (and their establishments) by linking them to all working-age individuals above the age of 16 for the period 1997-2011. We do, however, restrict our sample to firms with positive sales volumes to eliminate inactive firms.

\subsection{Job separations}

The aim of this study is to assess whether external offshoring triggers job separations in SMEs, where job separation is defined at the plant level as the end of an existing match between an employer and an employee. A major advantage of this definition is that the identification ID of the plant follows the establishment even if there is a change in ownership (i.e., a change of ID at firm level) or a change of location (i.e., moving personnel to a new location), as long as the plant has the same type of activity. Thus, our definition is robust to changes at firm level that have nothing to do with the activity of the plant. Although our definition allows us to identify job changes within a firm across plants (i.e., moving from one plant to another within the same firm), we will not be able to consider job changes within a plant. In addition, a potential drawback, which also applies to other studies, is that the reconstruction of a plant will be observed as a job separation, although the actual employment of the individual has not changed. Thus, layoffs or spin-offs may change the mix of personnel as well as the orientation of the activity of the plant, which can be accompanied by a new plant ID. According to our definition, a worker will, in this case, be identified as separated from his/her job when the old plant ID is dropped and the new one occurs although the type of employment may be the same. To mitigate potential biases due to wrongly specifying the same type of employment after a reconstruction as a new job, we exclude those individuals when more than ten employees are separated from a plant simultaneously and 50\% or more of them join the same plant in the same year. ${ }^{11}$ We also drop employee-employer job spells with gaps to mitigate any data input errors.

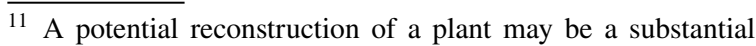
change in its production that may involve both lay-offs and new employments while some workers continue with the same type of employment as before. In such a situation, the plant will receive a new identification number, which implies that incumbent workers will be recorded as newly employed due to the new plant identification although they may have the same type of employment as under the old one. We therefore assume that a shift from one plant to another is less likely to be a substantial shift in a worker's employment if several co-workers switch simultaneously to the same plant.
} 
Fig. 2 Construction of job spells



Figure 2 illustrates how we define our sample and the worker's job spell. First, we consider all new spells starting after 1997 in the manufacturing sector. This implies that we focus on flow data (i.e., we exclude matches between employers and employees starting in 1997 or before) and that we can observe the number of jobs (according to our definition) an individual has between 1997 and 2011. ${ }^{12}$ The unique employer-employee match is based on the workplace from where the worker has her major source of income in a given year. The total number of job matches in our flow data amounts to 666,989. Second, as our data is based on annual observations, each spell time is defined as the number of years an individual is matched with the same plant. Third, a spell ends either with an observed job separation (i.e., the last year we observe an employeremployee match) or with a right-hand censored observation (i.e., when we do not know what happens after the last employer-employee observation). The share of spells defined as right-hand censored is around $43 \%$ of our sample. In turn, an observed job separation is divided into reconstruction (4\%) or exit (53\%). As discussed above, we exclude all spells ending with a reconstruction due to the uncertainty about whether these should be defined

\footnotetext{
12 The use of flow data is standard in the literature on job separations (see Munch, 2010, for an example in the literature on offshoring effects), which implies that the problem of left censoring is avoided. Note also that less than $2 \%$ of our sample stay on the same job for more than 12 years (Table 5 in the Appendix).
}

as job exits. ${ }^{13}$ Thus, the largest group is job exits, which consist of all employer-employee matches ending within the sample period. These exits can be further categorized with the help of information about the top income source the year after the job separation occurred. We are therefore able to identify the job separation as either exiting into a new job (45\%), into unemployment $(4 \%)$, into education $(2 \%)$, into retirement $(1 \%)$, or other $(1 \%) .^{14}$ Since we expect that the last two types of exits be mostly influenced by factors outside the employeremployee match, these are excluded from our sample. In this paper, we do not use the information on the different types of exits because we lack detailed information about the length of unemployment. Hence, we cannot separate between workers moving directly to a new job from workers moving to a new job via unemployment, since we only observe the major source of income the year after a job separation that might come from employment.

Leaving out job separations due to plant reconstruction, retirement, illness, or parental leave excludes 43,968 observations (or about $6 \%$ of all job separations during our period). This leaves us with a full sample consisting of 2,453,964 observations in the following three dimensions: 518,106 individuals,

\footnotetext{
13 A reconstruction can mean that individuals have the same work and employer but are linked to a new plant ID.

14 The last group includes exits due to illness and parental leave, as well as other minor outcomes.
} 
25,892 firms (with 29,173 plants), and 14 years, which form 622,963 unique employer-employee combinations. Table 5 in the Appendix shows the distribution of survivals and exits by spell duration, and the pattern resembles other datasets (see Munch, 2010). In our analysis, we will not use the complete set since we focus on external offshoring and therefore exclude firms with offshoring activities. Around $25 \%$ of all new jobs end after just 1 year, while only $2 \%$ of jobs surviving for 13 years end in the 13th year. Thus, almost $47 \%$ of all job separations are found during the first year, and only a small fraction $(0.4 \%)$ of employer-employee separations is at the end of the period.

\subsection{Measuring offshoring}

Our first step is to define offshoring within firms (internal offshoring), which forms the base for our main external offshoring measure. Helpman (2006) describes the firm's production structure in a strategic two-dimensional decision regarding the production of intermediate inputs. One dimension is whether the firm should keep production within the firm or not (i.e., whether to insource or outsource), while the other is whether to use domestic or foreign sources. Offshoring (i.e., shifting the location of manufacturing and service activities abroad) encompasses both international outsourcing, when the firm keeps an arm's length distance to its foreign supplier, and vertical FDI, when the domestic firm is supplied by a foreign affiliate. ${ }^{15} \mathrm{~A}$ crucial element in both cases of offshoring is that they involve importing tasks (or intermediates) from abroad instead of using domestic sources.

An important issue related to the type of imports to include in the measurement of offshoring. One point of departure is to include all types of imports. A potential drawback with such a broad definition is that it could include final goods that are not used as inputs in production. In addition, a broad measure may involve tasks that will never be produced domestically, neither in-house nor at arms-length. For example, Swedish firms are unlikely to consider a task such as drilling for oil domestically, suggesting that

\footnotetext{
$\overline{15}$ See Hummels et al. (2018) for an in-depth discussion about offshoring definitions and measurements.
}

imports of oil do not reflect a relocation of firms' production process where some part of it move overseas.

We deal with this by concentrating on imports of intermediate goods while excluding some intermediates that might not be produced domestically. In particular, we define a firm's offshoring as the firm's imports of processed goods mainly for industry, including parts and accessories, while imports of all other goods (i.e., raw material, fuel, capital goods, transport vehicles, and consumer goods) are excluded. ${ }^{16}$ Imports are import volumes or the value of imports in Swedish Krones (SEK). As a robustness test, we consider a narrower definition of offshoring in line with Feenstra and Hansson (1999), by focusing on imported products (again excluding raw materials, fuel, and finished machines) belonging to the same 3-digit industry as the firm. Feenstra and Hansson argue that this measure may capture the idea of offshoring even better as there is at least a potential for domestic production, if not by other firms then at least within the firm itself. ${ }^{17} \mathrm{~A}$ broader definition that includes all imports by the firm will also be tested.

Before we investigate offshoring activities over time, Table 6 in the Appendix compares some characteristics of individuals, plants, and firms depending on whether firms are involved in offshoring or not. Although four times as many individuals are employed by firms with offshoring activities, most firms and plants are not engaged in direct imports of inputs (almost 70\%). Workers in offshoring firms are however, on average, somewhat younger and they earn substantially more (around 100,000 SEK per year). Offshoring plants are also almost 9 times larger and have a higher share of white-collar labors. Finally, offshoring firms are much larger since their

\footnotetext{
${ }^{16}$ Here, we make use of the BEC (Broad Economic Categories) Rev. 4 classification and the codes used to define offshoring are $121,220,420,521$, and 530. These codes refer to intermediate products in manufacturing only as follows: 121 Food and beverages, processed, mainly for industry; 220 Industrial supplies not elsewhere specified, processed; 420 Parts and accessories of capital goods (except transport equipment); 521 Transport equipment, industrial; 530 Parts and accessories of transport equipment.

17 Contrary to our measurement, the Feenstra and Hanson (1999) definition of offshoring is made at the industry level. Similar measures have been used by, for example, Görg and Görlich (2015) and Munch (2010).
} 

offshoring at the firm level
Fig. 3 The importance of

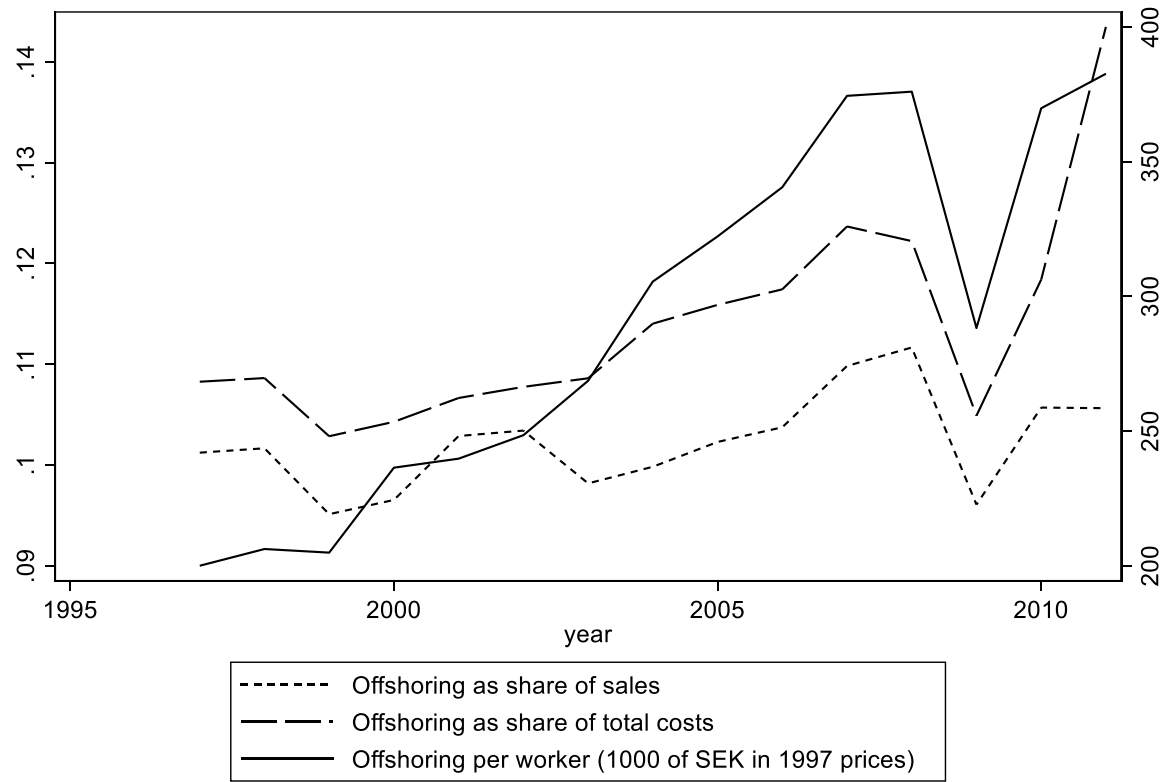

Fig. 4 The allocation of offshoring within sectors

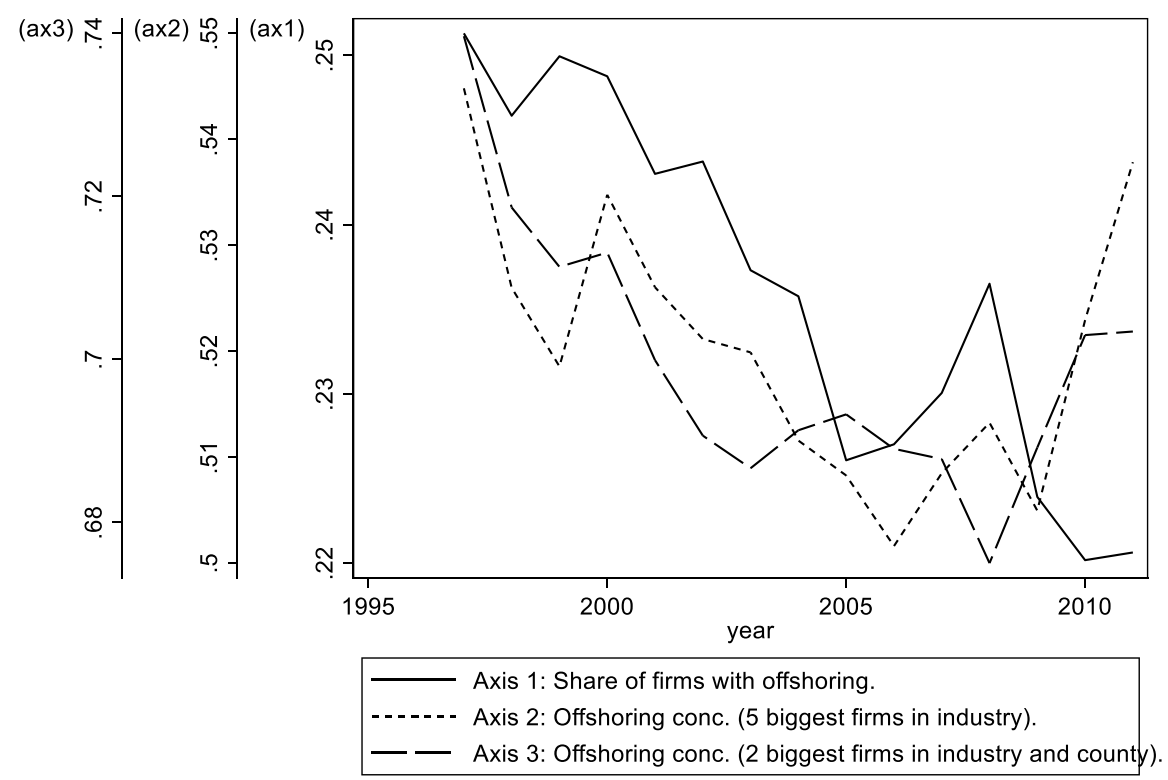

average sale volume is around 32 times higher, which results in a labor productivity that is almost 2.5 times higher. In other words, offshoring activity correlates positively with many characteristics used to measure good performance.

Figure 3 plots the ratios of offshoring at the firm level for manufacturing firms (weighted by firmlabor shares) to sales, total costs, and the number of employees. ${ }^{18}$ Interestingly, there does not appear to be a clear trend when it comes to offshoring to sales. This ratio remains quite stable at around $0.10-0.11$ over the period 1997-2011, which may reflect increased possibilities of exporting when better and/

18 These figures are based on all firms in the manufacturing sector and not only on those in our sample. 
or cheaper inputs are available to firms (i.e., imports and sales through exporting is raised in tandem). This is supported by the increasing importance of offshoring relative to total costs and number of employees. As illustrated, offshoring has increased from 11 to $14 \%$ of total costs, and offshoring per employee (in 000 s SEK at 1997 prices) has doubled between 1997 and 2011 (RHS axis). The only exception is during the financial crisis when production as well as trade of all firms dropped dramatically.

Figure 4 focuses on offshoring from a sector-level perspective by displaying the concentration pattern within 2-digit industries measured as the offshoring share of (i) the five largest offshoring firms per industry in total offshoring, (ii) the two largest firms per industry and county ${ }^{19}$ in total offshoring, and (iii) all firms that have some offshoring activity. One important observation is that offshoring activity is concentrated in a few firms. The five biggest offshoring firms within an industry form, on average, around 50\% of the total offshoring volume. Moreover, the level of concentration increases substantially as we turn to local markets. Looking at the two largest offshoring firms within each industry and county, we see that these firms account for, on average, $70 \%$ of the total offshoring volume. Thus, firms acting as suppliers of inputs to larger firms should be more concerned about offshoring patterns in their proximity rather than the overall concentration within an industry. There is not, however, a clear trend in the concentration shares, as both measures exhibit u-shaped patterns between 1997 and 2011. On the other hand, the share of firms with offshoring activities decreases over the observed period. In 1997, around 25\% of all firms (using weighted averages and sectors' labor shares as weights) offshored, while this share dropped to approximately $22 \%$ in $2011 .^{20}$

An important dimension of this paper is the complex linkages between firms, direct and indirect, that may give rise to external effects of offshoring on worker-job separations. Thus, a firm's offshoring could affect not only its own workers but also workers

\footnotetext{
19 A county is a Swedish administrative unit, and there are 21 different counties in Sweden.

${ }^{20}$ The same picture emerges if we look at the unweighted share of offshoring firms in total firms where this share drops from around 16 to $13 \%$ over the same period.
}

in other firms through, e.g., negative demand shocks. A problem, however, is that data on actual trade connections between firms are unavailable. Previous studies using industry-level measures of offshoring confound the external (or indirect) and the internal (or direct) effects on job separations, with the exception of the contributions by Merlevede and Michel (2020) and Egger and Egger (2005). Moreover, the industry-level measures have other drawbacks as they suggest not only identical effects across firms in the same industry, but also homogeneous effects across space. The latter problem suggests that distant offshoring activities will have the same weight as activities in the proximity.

In order to capture the indirect effects and the importance of local networks, we make use of a fine geographical division of Sweden called SAMS (Small Areas for Market Statistics). SAMS divides Sweden's 290 municipalities into 9209 small spatial areas, allowing us to create spatial variables without being concerned about the lumpiness of administrative borders at municipality level. ${ }^{21}$ Thus, we consider the geographical location of a plant $p$ belonging to a firm $f$ and construct the measure of external offshoring in the following steps. First, we allocate the firm's offshoring spatially across its plants. Since we cannot discriminate between locations when it comes to the impact of offshoring, we assume that the offshoring value of the plant is the same as the offshoring value of the firm. This assumption implies that a given offshoring volume has a similar impact at all stages of the firm's production line. Second, we construct the external offshoring that each plant faces (ignoring indexing for the firm) in a particular area $j$ as follows:

$Y_{p j t}=\left[\sum_{\omega \times \Omega j} y_{(\omega-p), t}\right]$

where $y_{(\omega-p), t}$ includes within-firm (internal) offshoring of the set of all establishments $\Omega$ located in SAMS $j$ excluding the observation plant $p$. Thus, the location-specific offshoring variable of plant $p$ does

\footnotetext{
21 Around $67 \%$ of the areas have an area less than $10 \mathrm{~km}^{2}$, while $89 \%$ have less than $100 \mathrm{~km}^{2}$. The minimum number of SAMS regions within a municipality is three, and the maximum is 877 .
} 
Fig. 5 The shades divide regions into quintiles, where the darkest shade represents the top quintile while the lightest shade indicates the bottom quintile. All figures use spatial lags with rowstandardized weights based on distance

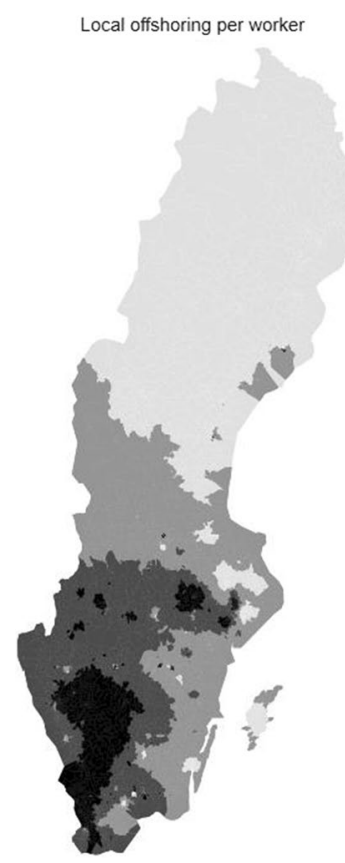

not include the plant's own possible internal offshoring volume. The variable $Y_{p j t}$ has the dimension of $J \times 1$ where $J$ is the number of SAMS areas in Sweden. Third, we make use of a spatial weight matrix to construct a localized measure of external offshoring giving a larger weight to offshoring activity in the proximity of the plant. We use a spatial weight matrix $W_{j}$ with the dimension $1 \mathrm{xJ}$ to define the spatial relationship between all SAMS areas in Sweden. We make use of an inverse distance function so that the localized external offshoring variable for plant $p$ located in SAMS area $j$ becomes:

$\tilde{Y}_{p t}=W_{j} Y_{p j t}=\sum_{r \in J}\left(y_{p j t} w_{j r}\right)$

where $w_{j r}=d_{j r}^{-1}$ is the distance in $\mathrm{km}$ between SAMS areas $j$ and $r$. In the case when $j=r$, we consider two alternative measures for the internal distance within each SAMS. The first sets the internal distance equal to one, which implicitly says that all plants are clustered together within a SAMS area. The second approximates the internal distance by using an average distance between plants with the help of the circle-radius of the SAMS area, i.e., $d_{j j}=0.67 \sqrt{\text { area } / \pi}$ (see Head \& Mayer, 2004). Our preferred measure is however a distance of one since it reflects the firms' tendency to cluster within SAMS areas.


Although we have a very fine spatial disaggregation, there may still be potential bias in our weights due to the underlying aggregation scheme leading to a variation in the size of the SAMS areas. We therefore use row standardization to mitigate this problem. This implies that the spatial weights for external distances $(j \neq r)$ become $w_{j r}=d_{j r}^{-1} / \sum_{r \neq j} d_{j r}^{-1.22}$. As the data on the location of plants across SAMS areas are incomplete before 2005, we restrict our study of the external effects to the period 2005-2011.

Figure 5 shows the spatial distribution of different local offshoring measures (per worker, total volume, and share of plants in the total local number of manufacturing firms) for each SAMS area plus their spatial lags (the spatial-weights are based on distance). The spatial distribution of the raw figures of the offshoring volumes correlates with the distribution of economic activities. Hence, most offshoring is found in a corridor from Stockholm to Gothenburg. The spatial distribution of offshoring concentration differs somewhat from this picture since the workers' local exposure to offshoring and the share of the local manufacturing plants engage in offshoring is concentrated in the central part of Southern Sweden. Workers' local

\footnotetext{
$\overline{22}$ We consider alternative spatial weight matrices as a robustness check. These are described in Sect. 3.3.
} 
exposure is, however, lower in the service dominated areas around Stockholm and Gothenburg (the two biggest cities in Sweden).

\subsection{Empirical model and covariates}

To assess the effects of offshoring on job separations, we follow the survival literature using flow data to take into account the dynamic implications of learning over time and its effect on job separations. Thus, we control for the length of each employer-employee match. ${ }^{23}$ There are also several advantages of using a flow sample. One is that overestimating the mean duration can be avoided, as stock samples tend to be biased towards longer spells (see Amemiya, 1999). Another is that problems related to left-truncation (i.e., a lack of information about the employeremployee match before 1997) can be ignored. The discrete nature of our data (the underlying continuous durations are recorded in discrete units) implies that a bivariate discrete-time hazard model $\left(\lambda_{m t}\right)$ for the employer-employee match $m$ at time $t$ can be employed $^{24}$ :

$$
\begin{aligned}
\lambda_{m t}\left(Z_{i p f j t}, \delta_{T}, \varepsilon_{m}\right) & =\operatorname{Pr}(\text { jobseparation }) \\
& =\operatorname{Pr}\left(T=t \mid T \geq t, Z_{i p f j t}, \delta_{T}, \varepsilon_{m}\right)
\end{aligned}
$$

where $T$ is the end time of a spell, $\delta_{T}$ is a non-parametric baseline hazard (i.e., duration dummies) common to all individuals, $\varepsilon_{m}$ is a time-invariant error term, and $Z_{i p f j t}$ is a vector with individual, plant, firm, and location characteristics. An advantage of a discrete duration model is that one could fit the hazard with a logit or a probit panel data model, where job separation takes the value of one if a match going on for $T$ years ends at time $t$, and zero otherwise. In the case of the probit model, our specification becomes $\operatorname{Pr}($ jobseparation $)=\Theta\left(\beta^{\prime} Z_{i p f j t}+\delta_{T}+\varepsilon_{m}\right)$ In addition to the offshoring variables discussed above, we control for a large set of individual, plant, firm,

\footnotetext{
23 This may be particularly important in the Swedish context due to labor laws, where the general principle of "last in first out" implies that the last person employed in an operating unit is the first who should be laid off in the case of redundancy.

24 The discrete-time hazard model, in the context of offshoring and job separations, has also been used by Geishecker (2012) and Görg and Görlich (2015). For a discussion on the discrete duration model, see Jenkins (1995), Gullstrand and Tezic (2008), and Hess and Persson (2012).
}

and regional characteristics influencing the probability of job separations. These are presented in Table 6 in the Appendix. With respect to the individual characteristics, we control for income, education, age (as cohort dummies), number of jobs during the observed period, gender, family, and Swedish nationality. Similar characteristics have been shown to be important for the job-separation decision in, for example, Munch (2010), Geishecker (2012), and Görg and Görlich (2015). As the literature strongly suggests that workers may be affected differently by offshoring depending on their characteristics, we also include interaction terms between the offshoring measures and a set of individual indicators. The plant and firm characteristics included are plant size (measured by the number of employees), firm productivity, and capital intensity. Although similar characteristics have been used in earlier studies on job separations and offshoring, we have more detailed information. Thus, while most previous studies control for the size of the firm, we focus on the size of the plant, which may be more important in situations with multi-plant firms. In addition, earlier studies measure characteristics reflecting productivity and capital intensity at the industry level, while we use the actual firm-level equivalent measures. Finally, we exploit detailed and fine information about the location of the plants to construct spatial measures of offshoring using spatial weights as explained above.

A potential problem when it comes to assessing the effects of offshoring on job-separations is the impact of unobserved variables influencing job separations. The rate of job turnovers and firms' offshoring possibilities varies across industries, and the economic structure of the local economy has a large impact on workers' job opportunities. If we are to control for these unobservable effects, our empirical specification needs to take the form of a complex panel with detailed fixed effects for plants, municipalities, years, or some combination of all of these. The use of panel data and instrumental variables makes the non-linear model highly complicated, and since we are only interested in the partial effects, we chose to use a linear probability model that has been shown to "give good estimates of the partial effects" (Wooldridge, 2010, p. 455; Angrist \& Pischke, 2008). We are comfortable with the linear probability model giving us good estimates, since the marginal effects from a probit model described 
above are very similar to those from a linear probability model when we run them with only year and duration dummies. ${ }^{25}$

\subsection{Instrumenting for offshoring}

All studies of the offshoring effect on employment or wages face potential endogeneity problems. Measures of offshoring at the industry level may suffer from simultaneous changes in technology and/or the composition of firms that will influence firms' demand for workers as well as offshoring activities (see the discussion in Hummels et al., 2018). Similar problems are found at the micro-level as productivity shocks not only affect the demand for offshoring because of output changes, but also the demand for workers. In addition, a firm's offshoring decision may be a reaction to job separations due to changes in the structure of the workforce. To deal with these endogeneity problems, we instrument for offshoring in a similar way as Hummels et al. (2014). The idea of this instrument is to use the variation of export supply in other countries that are exogenous to Swedish firms. Hence, we track the export variations of individual products in all countries and use these shocks on firm level (for internal offshoring) and regional (for external offshoring) level. The identification strategy therefore stems from that the variation in foreign countries' export patterns has little to do with changes in Swedish firm's technology or productivity. In addition, since these idiosyncratic shocks vary across countries and products, our instrument varies across firms and regions as long as their import pattern of inputs differs.

Hence, we start with product-specific export volumes at the 6-digit Harmonized System (HS) level of all countries except Sweden (from the COMTRADE database). Thereafter, the firms' presample distribution of product-specific imports (aggregated up from an 8-digit to a 6-digit HS-level) across countries is used to construct a firm-level instrument for internal offshoring. Formally, we construct the offshoring instrument for firm $f$ at time $t\left(M I V_{f t}\right)$ as follows:

\footnotetext{
25 These results are not presented in this paper but are available upon request.
}

$M I V_{f t}=\sum_{k}^{K} \sum_{c}^{C} s_{f c k} x_{c k t}$

where $x_{c k t}$ is country c's total exports of product $k$ (defined by HS6) at time $t$, and $s_{f c k}$ is firm $f$ 's import share of product $k$ from source $c$ defined at the presample period (1997 in this case). If the firm started to import after 1997, the first import year is used to define the shares.

One concern may be that the instrument becomes weaker and weaker over time if the import pattern in later periods diverges from the one in the pre-sample. Although we do find that new import links emerge over time, the initial pattern still appears to be quite consistent, as $58 \%$ of the sample's total imports in 2011 are formed by the same source-product combination that appears in each firm's pre-sample distribution (i.e., in $s_{f c k}$ ). Another concern is the possibility that the export supply of other countries is influenced by large Swedish importers (i.e., Swedish firms with buyer bargaining power). However, this seems to be a minor problem for imports. Focusing on the most important import product (in values) of each firm, the share of Swedish imports in total world imports range between 0 and 0.36 , with a distribution highly skewed towards zero (e.g., the 99th percentile is around 6\%). Although the share of Swedish imports on a bilateral basis is larger, ranging between 0 and 0.5 , the median is not more than $12 \%$, and the 90th percentile is as low as $36 \%$.

The instrument for external offshoring is similarly constructed by using $M I V_{f t}$ from Eq. (3). In other words, the instrument for external offshoring is the (spatially) weighted sum of the calculated $M I V_{f t}$ for all firms within a SAMS area excluding the firm itself. Since the spatial data only covers the period 2005 to 2011, the distribution key $s_{f c k}$ is now defined for the year 2004. In this case, $69 \%$ of total imports in 2011 have the same source-product combination as in 2004. Figure 6 shows the correlation between the offshoring measure and the instrument.

\section{Results}

This section presents the results from estimating the probability of job separations at the worker-plant level following internal and external offshoring. 
Fig. 6 Scatter plot of the preferred external offshoring measure and the instrument

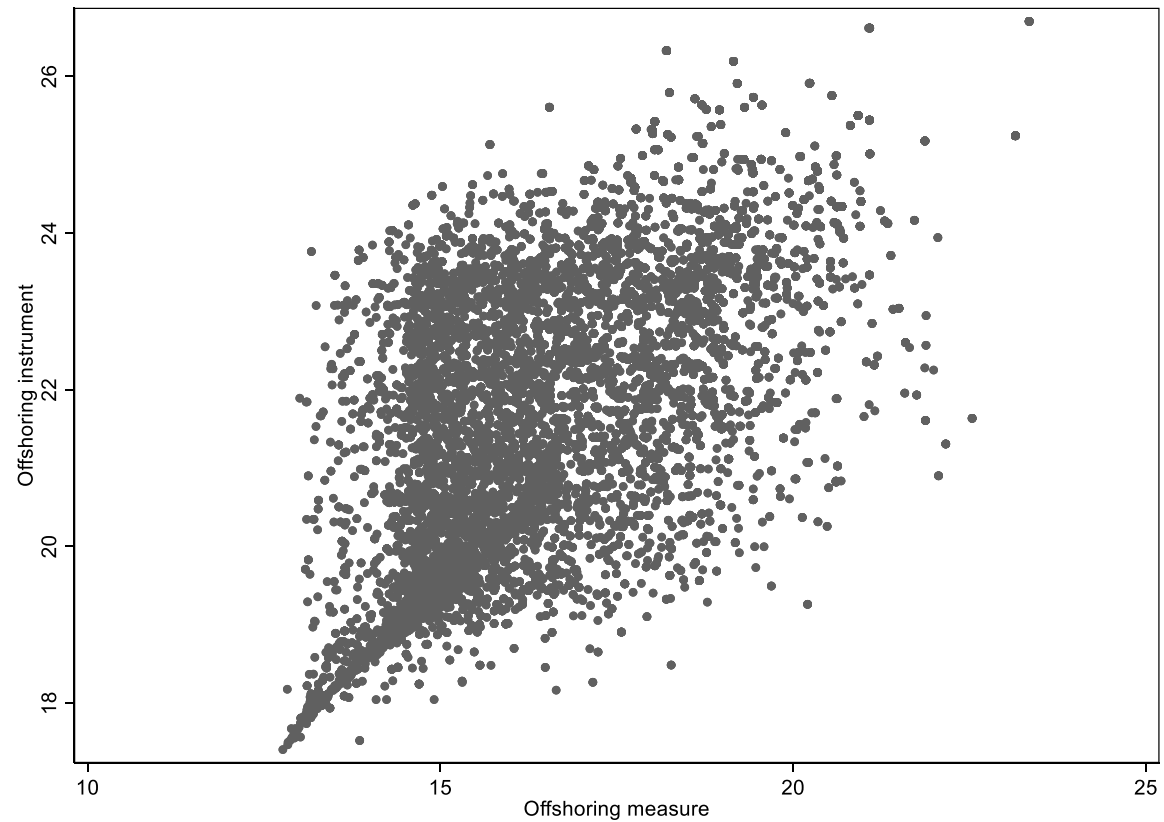

When assessing the effects of external offshoring, we split the sample into firms that also offshore themselves, and firms that have no offshoring activities on their own. We start by pooling all firms regardless of size and then continue by dividing our sample into SMEs and large firms.

Equation (4) is first estimated using a linear probability model with and without the instrumental variable discussed in Sect. 2.4. For the IV estimations, the first-stage regressions (presented in the Appendix Table 7) show that the instrument has the expected positive sign and is highly significant. In addition, the Kleibergen-Paap F-statistic is well above the rule of thumb of 10. All estimations include plant, municipality-year, and spell duration fixed effects. Note that worker-fixed effects are not possible to include in the estimations, as their inclusion would drop all right-hand-censored observations. We also use plant and not firm fixed effects because we follow employees at the plant-level in the data. Standard errors are clustered at the SAMS-year level to control for potential correlation between workers within the local market.

We start our analysis in Table 1 with a comparison between internal and external offshoring including all firms. This allows us to compare our results with other studies in the literature and to contrast the effects between large firms and SMEs. Columns (1) and (2) look at internal offshoring and include only offshoring firms, while columns (3) and (4) focus on external offshoring with the sample divided into employees in offshoring and non-offshoring firms, respectively. ${ }^{26}$ Note that the regressions with external offshoring are based on a shorter period (2005-2011) due to the lack of reliable spatial information before 2005. Recall that the offshoring measure in all regressions pertains to the volume of imported intermediate goods as defined in Sect. 2.2.

The table also includes the interaction terms between the offshoring measures and three different individual indicators in order to capture asymmetric effects of offshoring across workers. ${ }^{27}$ The first indicator is a dummy variable for skill level (high skill=1), which captures individuals with at least 3 years of university education. We expect that the probability of exiting due to offshoring falls with education if offshoring complements skilled workers (see, e.g., Munch, 2010). The second is a cohort dummy taking the value of one when the individual belongs to the first or the second cohort (i.e., is

\footnotetext{
${ }^{26}$ Non-offshoring firms (and hence plants) are defined as firms that do not offshore at all during the sample period.

${ }^{27}$ Excluding interaction terms leads to an insignificant offshoring effect.
} 
Table 1 Estimating worker-plant job separation: controlling for heterogeneity

\begin{tabular}{|c|c|c|c|c|}
\hline \multirow[t]{3}{*}{ Variable } & \multicolumn{2}{|c|}{ Internal offshoring } & \multicolumn{2}{|c|}{ External offshoring } \\
\hline & & IV & IV (off. firms) & IV (non-off. firms) \\
\hline & (1) & (2) & (3) & (4) \\
\hline \multicolumn{5}{|l|}{ Worker level } \\
\hline High-skilled & $\begin{array}{l}0.053 * * * \\
(0.000)\end{array}$ & $\begin{array}{l}0.023 \\
(0.529)\end{array}$ & $\begin{array}{l}0.114 * * * \\
(0.000)\end{array}$ & $\begin{array}{l}0.164 * * * \\
(0.001)\end{array}$ \\
\hline Ln (income) & $\begin{array}{l}-0.055^{* * *} \\
(0.000)\end{array}$ & $\begin{array}{l}-0.055^{* * *} \\
(0.000)\end{array}$ & $\begin{array}{l}-0.039 * * * \\
(0.000)\end{array}$ & $\begin{array}{l}-0.039 * * * \\
(0.000)\end{array}$ \\
\hline Ln (number of jobs) & $\begin{array}{l}0.022 * * * \\
(0.000)\end{array}$ & $\begin{array}{l}0.022 * * * \\
(0.000)\end{array}$ & $\begin{array}{l}0.017 * * * \\
(0.000)\end{array}$ & $\begin{array}{l}0.035 * * * \\
(0.000)\end{array}$ \\
\hline Female & $\begin{array}{l}-0.013 * * * \\
(0.000)\end{array}$ & $\begin{array}{l}-0.013 * * * \\
(0.000)\end{array}$ & $\begin{array}{l}-0.012 * * * \\
(0.000)\end{array}$ & $\begin{array}{l}-0.011 * * * \\
(0.066)\end{array}$ \\
\hline Swedish & $\begin{array}{l}0.028 * * * \\
(0.000)\end{array}$ & $\begin{array}{l}0.028 * * * \\
(0.000)\end{array}$ & $\begin{array}{l}0.022 * * * \\
(0.000)\end{array}$ & $\begin{array}{l}0.022 * * * \\
(0.000)\end{array}$ \\
\hline Family & $\begin{array}{l}-0.002 * * * \\
(0.001)\end{array}$ & $\begin{array}{l}-0.003 * * * \\
(0.001)\end{array}$ & $\begin{array}{l}-0.002 * * \\
(0.043)\end{array}$ & $\begin{array}{l}-0.005^{* * *} \\
(0.000)\end{array}$ \\
\hline \multicolumn{5}{|l|}{ Firm/plant level } \\
\hline Ln (internal offshoring) & $\begin{array}{l}0.002 \\
(0.195)\end{array}$ & $\begin{array}{l}0.013 * * * \\
(0.010)\end{array}$ & $\begin{array}{l}-0.000 \\
(0.933)\end{array}$ & \\
\hline Ln (TFP) & $\begin{array}{l}0.006 * * * \\
(0.002)\end{array}$ & $\begin{array}{l}0.004 \\
(0.187)\end{array}$ & $\begin{array}{l}0.010 * * * \\
(0.001)\end{array}$ & $\begin{array}{l}0.004 * * \\
(0.032)\end{array}$ \\
\hline Ln (capital intensity) & $\begin{array}{l}0.004 \\
(0.195)\end{array}$ & $\begin{array}{l}0.003 \\
(0.243)\end{array}$ & $\begin{array}{l}0.011 * * * \\
(0.005)\end{array}$ & $\begin{array}{l}-0.007 * * * \\
(0.007)\end{array}$ \\
\hline Ln (workforce(plant)) & $\begin{array}{l}0.027 * * * \\
(0.000)\end{array}$ & $\begin{array}{l}0.026 * * * \\
(0.000)\end{array}$ & $\begin{array}{l}0.036 * * * \\
(0.000)\end{array}$ & $\begin{array}{l}0.060 * * * \\
(0.000)\end{array}$ \\
\hline \multicolumn{5}{|l|}{ Regional level } \\
\hline Ln (external offshoring) & & & $\begin{array}{l}-0.032 * * \\
(0.017)\end{array}$ & $\begin{array}{l}0.024 * * \\
(0.018)\end{array}$ \\
\hline \multicolumn{5}{|l|}{ Firm level: } \\
\hline $\begin{array}{l}\text { High-skilled } \times \text { Ln (internal } \\
\text { offshoring) }\end{array}$ & $\begin{array}{l}-0.002 * * \\
(0.000)\end{array}$ & $\begin{array}{l}-0.000 \\
(0.921)\end{array}$ & $\begin{array}{l}-0.002 \\
(0.109)\end{array}$ & \\
\hline $\begin{array}{l}\text { Young worker } \times \text { Ln (internal } \\
\text { offshoring) }\end{array}$ & $\begin{array}{l}-0.002 * * \\
(0.000)\end{array}$ & $\begin{array}{l}-0.010 * * * \\
(0.000)\end{array}$ & $\begin{array}{l}0.001 \\
(0.735)\end{array}$ & \\
\hline $\begin{array}{l}\text { New worker } \times \text { Ln (internal } \\
\text { offshoring) }\end{array}$ & $\begin{array}{l}-0.004 * * * \\
(0.000)\end{array}$ & $\begin{array}{l}-0.005 * * * \\
(0.000)\end{array}$ & $\begin{array}{l}-0.005^{* * *} \\
(0.002)\end{array}$ & \\
\hline \multicolumn{5}{|l|}{ Regional level: } \\
\hline $\begin{array}{l}\text { High-skilled } \times \text { Ln (external } \\
\text { offshoring) }\end{array}$ & & & $\begin{array}{l}-0.003^{*} \\
(0.088)\end{array}$ & $\begin{array}{l}-0.007 * * * \\
(0.003)\end{array}$ \\
\hline $\begin{array}{l}\text { Young worker } \times \text { Ln (external } \\
\text { offshoring) }\end{array}$ & & & $\begin{array}{l}-0.003 \\
(0.236)\end{array}$ & $\begin{array}{l}-0.003 * * \\
(0.040)\end{array}$ \\
\hline $\begin{array}{l}\text { New worker } \times \text { Ln (external } \\
\text { offshoring) }\end{array}$ & & & $\begin{array}{l}-0.012 * * * \\
(0.000)\end{array}$ & $\begin{array}{l}-0.011 * * * \\
(0.000)\end{array}$ \\
\hline
\end{tabular}


Table 1 (continued)

\begin{tabular}{lllll}
\hline Variable & Internal offshoring & & \multicolumn{2}{l}{ External offshoring } \\
\cline { 4 - 5 } & OLS & IV & IV (off. firms) & IV (non-off. firms) \\
& $(1)$ & $(2)$ & $(3)$ & $1,082,144$ \\
\hline Observations & $1,643,788$ & $1,643,788$ & 0.140 & 0.205 \\
$R$-squared & 0.152 & 0.150 & 14.66 & 80.66 \\
Kleiberger-Paap F stat & & 52.07 & & \\
\hline
\end{tabular}

All regressions include plant, municipality-year, and spell duration fixed effects. Cohort age group dummies are also included. Robust p-values (in parentheses) are based on standard errors clustered at SAMS-year level. ***, **, and * denote statistical significance at the 1,5 , and $10 \%$ significance levels, respectively.

younger than 40$).^{28}$ The expected impact of its interaction with offshoring on the probability of exiting is ambiguous, since it may reflect less experienced workers (hence increasing the probability), or it may reflect a new generation of workers with a new set of skills (hence lowering the probability). ${ }^{29}$ The final indicator is a dummy variable reflecting whether the individual has been matched with the employer for less than 3 years capturing newly employed individuals. How the risk of a job separation from offshoring is affected by this indicator is uncertain as well. On the one hand, the Swedish "last in first out" principle suggests that the probability of a job separation due to offshoring may be larger for new employees. On the other hand, the probability may fall if increased offshoring involves building up new operating units or hiring new types of competences.

Starting with the individual characteristics, we note that the estimations yield the expected signs. Hence, workers who are skilled (or highly educated), have Swedish nationality, or have switched jobs more frequently before are more likely to exit a job spell at any point in time, signaling their higher mobility. On the other hand, higher income, being female, or having a family is negatively associated with the probability of a job exit. Turning to the firm- and plant-level characteristics, we find that both plant size and TFP have

\footnotetext{
${ }^{28}$ Recall that we include cohort dummies in all regressions but we do not report the coefficients of these variables in the tables for the sake of brevity and presentation.

${ }^{29}$ Holger and Görlich (2015) include an experience variable (i.e., number of years with full-time work) and find that experience matters for the probability of exiting but with opposite effects for less-skilled and skilled individuals. Hence, while experience increases job separations for high-skilled, it decreases job separations for the low-skilled.
}

a positive impact on job separation in all estimations, demonstrating how increases in size and productivity are associated with a higher risk of a job exit for the individual. This could be due to a positive correlation between productivity growth and savings on labor costs, or that plant growth is related to an internal restructuring process leading to higher job turnover. For capital intensity, the results are less clear. While an increase in capital intensity has a positive (but mostly insignificant) relationship with job turnover in columns (1)-(3), it has a negative impact in column (4), which includes only workers in firms that do not offshore themselves. Since the group of non-offshoring firms mostly consists of small and medium-sized enterprises, the result suggests that capital accumulation in SMEs is more likely to act as a complement than a substitute to labor.

Considering the effects of offshoring itself, we find an effect of internal offshoring on job separation in the IV estimation in column (2) on a sample with all offshoring firms and without including external offshoring. The result indicates that an increase of internal offshoring of $10 \%$ increases the probability of a job separation by around $0.13 \%$. As the average increase of internal offshoring is $27 \%$ over our observed period, the probability of exiting increased by around $0.35 \%$ over the period. This effect is quite modest compared to the results for low-skilled workers in Munch (2010) and Görg and Görlich (2015). ${ }^{30}$

\footnotetext{
$\overline{30}$ Görg and Görlich (2015) find the probability of a job separation for low-skilled workers with a temporary contract to increase by $0.12 \%$ as offshoring increases by one percentage point. Munch (2010) focuses on the unemployment risk of workers with basic skills and finds that a one percentage point increase of outsourcing leads to an increased unemployment risk of $1.29 \%$.
} 
The differences in estimated magnitudes between this study and previous studies could be due to the choice of data level. In particular, the higher risk of a job exit from increased offshoring when measured at the industry level may be because this measure captures industry dynamics as well as offshoring carried out by other firms within the industry.

It should be noted that the increased probability of $0.13 \%$ is for the base group, which consists of older employees (in terms of age and number of years in the firm), without university education. Looking at the results for the interaction terms, we see that the increased risk of a job separation from internal offshoring is reduced for the newly employed workers and almost entirely disappears for the young cohort of workers. On the other hand, the level of education does not seem to matter. ${ }^{31}$ The results therefore suggest that the job destruction part of offshoring is more about pushing out older workers. ${ }^{32}$

Turning to our focus to external offshoring in columns (3) and (4), we find the results to be very different between workers in offshoring and non-offshoring firms. Note that external offshoring is only measured for the period between 2005 and 2011, and, therefore, the results that include the effects of external offshoring only pertain to this shorter period. ${ }^{33}$ For workers in firms that also perform offshoring on their own, the result in column (3) indicates that a $10 \%$ increase in offshoring by other firms in the proximity decreases the probability of a job separation by around $0.3 \%$. This lower probability of a job exit from external offshoring may indicate that offshoring firms benefit from their access to cheaper and/or better inputs through their offshoring activities. For workers in non-offshoring firms, the result is the opposite: a $10 \%$ increase in external offshoring now increases the likelihood of a job exit for our base group by $0.24 \%$, an impact that is almost twice as large compared to the

\footnotetext{
31 This result is in line with Andersson et al., (2016, 2017) which find no effects of material offshoring on the firm's relative demand for high-skilled workers.

32 Including only one of the interaction terms at a time does not change the results for these coefficients.

33 The specification in Table (1) column (2) has also been estimated for the shorter period between 2005 and 2011, and the results are similar (and available upon request) in sign and magnitude although the shorter sample period implies less precisely estimated coefficients for internal offshoring and its interaction term.
}

internal offshoring effect. Taking into account the asymmetric effects across workers, we further find that the probability of a job exit for workers in nonoffshoring firms is reduced by having an education, being under 40, and being newly employed. In fact, a newly employed, young individual with a university degree faces an almost zero-increased risk of a job separation due to offshoring. The most important reduction stems from being newly employed, closely followed by a university degree, and thereafter belonging to the younger cohort. Workers in offshoring firms also face a reduced risk of a job separation due to offshoring when it comes to education (although the interaction term is only significant at the $10 \%$ level) and being new to the job, but the impact of offshoring by other firms remains negative.

The asymmetric effects suggest that offshoring triggers Schumpeterian dynamics, as it increases the exit rate of older and longer-employed workers with lower education, while newly employed and younger workers with a university degree are more likely to stay. We find some tentative evidence for this dynamic view when comparing the education and the occupation of newly employed workers with those that exit (i.e., we compare the first year of entering workers with the exit year of those leaving an employment). The results show that workers ending their job have, in general, a lower educational level and are less likely to have a white-collar job. This relationship is even stronger in areas that have a higher degree of external offshoring than the average location. Hence, it seems that offshoring accelerates job churning. ${ }^{34}$

The different effects of external offshoring on workers in offshoring and non-offshoring firms may illustrate the difference between these two types of firms in coping with shocks. With respect to offshoring firms, we also see that the inclusion of external offshoring in column (3) removes the impact of the firm's own offshoring on job exit by the worker. This

\footnotetext{
$\overline{34}$ These results are based on a specification focusing on nonoffshoring firms and a binary indicator taking the value 1 if the worker exits a job and 0 if the worker enters. The exit dummy is regressed on a set of binary variables indicating whether the worker is high-skilled and white-collar, and these are interacted with a binary variable reflecting whether the location has more than the average exposure to external offshoring (controlling for individual income, county fixed effects, and timefixed effects). The results are not presented in the paper but are available upon request.
} 
Table 2 Estimating worker-plant job separation: firms of different size

Variable Small and medium-sized firms (up to 249 employees)

\begin{tabular}{lll}
\hline Internal offsh & \multicolumn{2}{l}{ External offshoring } \\
\cline { 2 - 3 } IV & IV (off. firms) & IV (non-off. firms) \\
(1) & (2) & (3)
\end{tabular}

(1)

(2)

(3)

Firm/plant level

Ln (internal offshoring)

$\begin{array}{ll}0.012 * * * & -0.002 \\ (0.008) & (0.797)\end{array}$

Regional level

Ln (external offshoring)

$-0.004$

$0.022 * *$

(0.838)

(0.038)

Interactions

Firm level:

High-skilled × Ln (internal offshoring)

$\begin{array}{ll}0.009 * * & -0.002 \\ (0.041) & (0.109) \\ -0.016^{* * *} & -0.002 \\ (0.000) & (0.605) \\ -0.005^{* *} & -0.005^{*} \\ (0.028) & (0.062)\end{array}$

Regional level:

High-skilled $\times$ Ln (external offshoring)

$-0.001$

$-0.006^{* *}$

(0.653)

(0.018)

Young worker $\times$ Ln (external offshoring)

$-0.001$

$-0.003 * *$

(0.694)

(0.093)

New worker $\times \operatorname{Ln}$ (external offshoring)

$-0.013 * * *$

$-0.008 * * *$

(0.000)

(0.000)

Observations

521,656

346,833

509,700

Variable

Large firms (250 employees and more)

Internal offsh

IV

(4)

$\begin{array}{ll}0.0018 & -0.003 \\ (0.106) & (0.819)\end{array}$

Regional level

Ln (external offshoring)

Interactions

Firm level:

High-skilled $\times$ Ln (internal offshoring)

$$
\begin{aligned}
& -0.001 \\
& (0.741) \\
& -0.013 * * * \\
& (0.002) \\
& -0.007 * * * \\
& (0.000)
\end{aligned}
$$$$
-0.003
$$$$
\text { (0.222) }
$$$$
0.002
$$$$
\text { (0.726) }
$$$$
-0.008 * *
$$

New worker $\times$ Ln (internal offshoring)

(0.010)
0.037

(0.413) 
Table 2 (continued)

\begin{tabular}{llll}
\hline Variable & \multicolumn{2}{l}{ Small and medium-sized firms (up to 249 employees) } \\
\cline { 2 - 4 } & Internal offsh & \multicolumn{2}{l}{ External offshoring } \\
\cline { 3 - 4 } & IV & $\frac{\text { IV (off. firms) }}{(2)}$ & IV (non-off. firms) \\
\hline Regional level: & $(1)$ & $-0.003)$ \\
High-skilled $\times$ Ln (external offshoring) & & $(0.203)$ & $-0.014^{*}$ \\
Young worker $\times$ Ln (external offshoring) & & -0.003 & $(0.072)$ \\
New worker $\times$ Ln (external offshoring) & & $(0.419)$ & -0.002 \\
Observations & $1,122,028$ & $-0.010^{* * *}$ & $-0.043^{* * *}$ \\
\hline
\end{tabular}

Only the results for the offshoring variables and their interactions are reported. The regressions include all other worker and firm controls as in Table 1. All regressions include plant, municipality-year, and spell duration fixed effects. Cohort age group dummies are also included. Robust $p$-values (in parentheses) are based on standard errors clustered at SAMS-year level. ***, **, and * denote statistical significance at the 1,5 , and $10 \%$ significance levels, respectively.

finding suggests that the direct effect of offshoring found in column (2) could be a result of the firm being geographically located near other offshoring firms that correlate with the firm's own offshoring behavior.
Having established the different effects between workers in offshoring and non-offshoring firms, we now turn to the effects of offshoring on workers in firms of different sizes. Recall that the discussion in the introduction suggests that smaller firms may be

Table 3 Estimating worker-plant job separation: alternative off-shoring measures-effects on non-offshoring SMEs only

\begin{tabular}{|c|c|c|c|c|c|c|}
\hline \multirow{2}{*}{$\begin{array}{l}\text { Offshoring per- } \\
\text { formed by: } \\
\text { Offshoring defini- } \\
\text { tion }\end{array}$} & \multicolumn{3}{|l|}{ All firms } & \multicolumn{3}{|c|}{ Firms in same industry only } \\
\hline & $\begin{array}{l}\text { All intermediates } \\
\text { (from baseline) }\end{array}$ & $\begin{array}{l}\text { Total imports } \\
\text { (broader) }\end{array}$ & $\begin{array}{l}\text { Intermediates } \\
\text { belong to same } \\
\text { industry (narrow) }\end{array}$ & All intermediates & Total imports & $\begin{array}{l}\text { Intermediates } \\
\text { belong to same } \\
\text { industry }\end{array}$ \\
\hline Variable & (1) & (2) & (3) & (4) & (5) & (6) \\
\hline \multicolumn{7}{|l|}{ Regional level } \\
\hline $\begin{array}{l}\text { Ln (external off- } \\
\text { shoring) }\end{array}$ & $\begin{array}{l}0.022 * * \\
(0.038)\end{array}$ & $\begin{array}{l}0.020 * * \\
(0.000)\end{array}$ & $\begin{array}{l}0.026 * * \\
(0.069)\end{array}$ & $\begin{array}{l}0.010 * * \\
(0.030)\end{array}$ & $\begin{array}{l}0.014 * * \\
(0.014)\end{array}$ & $\begin{array}{l}0.010 \\
(0.124)\end{array}$ \\
\hline \multicolumn{7}{|l|}{ Interactions } \\
\hline \multicolumn{7}{|l|}{ Regional level: } \\
\hline $\begin{array}{l}\text { High-skilled } \times \text { Ln } \\
\text { (external offshor- } \\
\text { ing) }\end{array}$ & $\begin{array}{l}-0.006^{* *} \\
(0.018)\end{array}$ & $\begin{array}{l}-0.004 * \\
(0.080)\end{array}$ & $\begin{array}{l}-0.005^{*} \\
(0.075)\end{array}$ & $\begin{array}{l}-0.001 \\
(0.544)\end{array}$ & $\begin{array}{l}-0.002 \\
(0.265)\end{array}$ & $\begin{array}{l}-0.002 \\
(0.384)\end{array}$ \\
\hline $\begin{array}{l}\text { Young worker } \\
\times \text { Ln (external } \\
\text { offshoring) }\end{array}$ & $\begin{array}{l}-0.003 * * \\
(0.093)\end{array}$ & $\begin{array}{l}-0.003^{* *} \\
(0.056)\end{array}$ & $\begin{array}{l}-0.003 * * \\
(0.072)\end{array}$ & $\begin{array}{l}-0.004 * * * \\
(0.001)\end{array}$ & $\begin{array}{l}(-0.005)^{* * *} \\
(0.000)\end{array}$ & $\begin{array}{l}-0.003 * * * \\
(0.002)\end{array}$ \\
\hline $\begin{array}{l}\text { New worker } \times \text { Ln } \\
\text { (external offshor- } \\
\text { ing) }\end{array}$ & $\begin{array}{l}-0.008 * * * \\
(0.000)\end{array}$ & $\begin{array}{l}-0.012 * * * \\
(0.000)\end{array}$ & $\begin{array}{l}-0.012 * * * \\
(0.000)\end{array}$ & $\begin{array}{l}-0.001 \\
(0.363)\end{array}$ & $\begin{array}{l}-0.003^{*} \\
(0.100)\end{array}$ & $\begin{array}{l}-0.001 \\
(0.682)\end{array}$ \\
\hline Observations & 509,700 & 509,700 & 509,700 & 509,700 & 509,700 & 509,700 \\
\hline
\end{tabular}

See Table 2 
Table 4 Estimating worker-plant job separation: alternative spatial weight matrix—non-offshoring SMEs only

\begin{tabular}{llll}
\hline & No-row standardization & & \\
\cline { 2 - 4 } & & $<60 \mathrm{~km}$ & $<60 \mathrm{~km}, 60 \mathrm{to} 100 \mathrm{~km}$ \\
\hline Variable & IV (non-off. firms) & IV (non-off. firms) & IV (non-off. firms) \\
& $(1)$ & $(2)$ & $(3)$ \\
Regional level & & & $0.014^{* *}$ \\
Ln (external offshoring) & $0.010^{* *}$ & $0.014^{* *}$ & $(0.016)$ \\
Ln (external offshoring60-100 km) & $(0.020)$ & $(0.016)$ & $-0.11(0.415)$ \\
Interactions & & & $-0.005^{*}$ \\
High-skilled $\times$ Ln (external offshoring) & $-0.003^{* *}$ & -0.000 & $(0.075)$ \\
Young worker $\times$ Ln (external offshoring) & $(0.011)$ & $(0.857)$ & $-0.003^{* *}$ \\
New worker $\times$ Ln (external offshoring) & -0.001 & -0.002 & $(0.072)$ \\
Observations & $(0.140)$ & $(0.3903)$ & $-0.012^{* * *}$
\end{tabular}

See Table 2

more vulnerable to external offshoring as these are more closely connected to the local market. Evidence from Sweden as well as other countries indicates that smaller firms sell higher shares of their sales locally, implying that these firms may be more influenced by local shocks caused by offshoring. Thus, we divide our sample into workers in SMEs (up to 249 employees) and large (at least 250 employees) firms. Table 2 presents the results for our main variables of interest from the IV estimations for the two groups of firms. A noticeable result (see columns (1) for the two groups) is that the impact of internal offshoring that we found for the whole sample is only found for SMEs (the magnitude also being similar), while employees in large firms seem to be unaffected.

Another striking result is that the impact of external offshoring on job separation only applies to nonoffshoring and smaller firms (column (3)), and both the magnitudes and the interaction patterns are similar to what we find in Table 1. In addition, the negative effect of external offshoring on the likelihood of a job separation only applies to large firms (column (2)) as more offshoring in the proximity reduces job separations among their employees. One explanation for this result could be that offshoring among firms in the local network is associated with agglomeration economies making jobs more stable. That is, an increase of offshoring in the neighborhood suggests that local upstream firms are negatively affected by this increased competition from cheaper or better inputs in their proximity, which leads to an indirect relocation effect as job separations increase in these firms. At the same time, a surge in offshoring in the proximity of a larger firm implies that it has access to cheaper and/or better inputs from local offshoring suppliers, and hence, it seems to improve the local production network so that jobs in the larger firm become more secure.

\subsection{Robustness}

This section investigates the robustness of our results to several dimensions. As we have found offshoring mainly influences the job security of workers in nonoffshoring SMEs negatively, we focus on these types of firms unless otherwise stated. ${ }^{35}$ While some of the results are presented, other results are available from the authors upon request. First, we establish that our results are robust to changes in cluster groups and fixed effects. The standard errors increase somewhat when we cluster by SAMS region or plant level instead of SAMS year, but the level of significance is still below 5\%. When it comes to fixed effects, the magnitude of the effect of

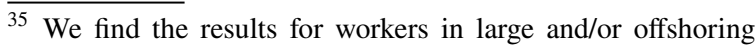
firms robust as well. Note also that the results are robust to including exits defined as job reconstruction.
} 
external offshoring on the probability of exit falls as we move up to firm and industry level instead of plant level. This suggests that there are important unobserved plant/location-specific effects (not captured in earlier studies) that not only increase job insecurity but also correlate with external offshoring.

Secondly, we test for other measures of internal and external offshoring. As discussed in Sect. 2.2, one concern is that a broad measure of offshoring may encompass products that domestic firms would not consider producing on their own and will therefore fail to capture the idea of an active decision by the firm to use domestic or foreign sources. Hence, we follow Feenstra and Hanson (1999) and use a narrower definition based on imports of products (excluding raw materials, fuels, and finished machines) belonging to the same industry (3-digit level) as the offshoring firm in the main results. Here, we include all products sold by all firms in the industry and not just by the firm itself, in order to capture the possibility of switching from domestic outsourcing to offshoring. ${ }^{36}$ In addition, we also investigate a broader measure based on total imports by the firm. Table 3 presents the results for these alternative measures for non-offshoring SMEs. Column (1) repeats the baseline estimate (Table 2 column 3 ) for ease of exposition. Columns (2) and (3) include offshoring of all firms, while columns (4)-(6) narrow the focus even further by including only offshoring performed by firms that belong to the same industry as the plant in which the worker facing external offshoring is employed. Using both, the broader and narrower measures do not seem to change the results; the coefficient on the external offshoring variable is slightly smaller in the broader measure and slightly bigger in the narrow measure case. Restricting offshoring (for the external offshoring measure) to the firms that belong to the same industry as the nonoffshoring firm also largely produces robust results albeit with smaller coefficients on the effect of external offshoring. This is expected since the offshoring performed will be smaller in this scenario.

We also use alternative spatial weight matrices in the measures of external offshoring. One is the inverse distance but without a row-standardized weight

\footnotetext{
36 This definition differs from the study of Hummels et al. (2014), which focuses on imports from the same product category (HS4 or HS2) as the one sold by the firm (excluding raw materials and finished machines).
}

matrix. Another is the row-standardized radial distance weight, which determines a binary relationship between areas by taking the value one if the location is within some distance $d$ of the location of plant $p$, and zero otherwise. Using these alternative weights, in combination with the other measures of offshoring described above, provides comparable results as before. Table 4 shows the results using the inverse distance without a row-standardized weight matrix with our preferred measure of offshoring. In column (2), we restrict external offshoring to a distance within $60 \mathrm{~km}$ of the plant, which increases the probability of a job separation. The importance of the local economy is emphasized in column (3) when we add external offshoring of firms located further away (between 60 and $100 \mathrm{~km}$ ), since this has no impact on job separation.

To further investigate the importance of the local economy, we divide external offshoring into (1) offshoring by other firms co-located in the same SAMS area and (2) the spatially weighted offshoring measure of all other SAMS areas. The results from this separation between one co-location part and one neighboring part suggest that employees in non-offshoring firms are mostly influenced by offshoring firms in their immediate surrounding, as the neighboring part is insignificant while the co-location part is significant at the $1 \%$ level. The magnitude of the co-location part differs, however, when we use different measures of the internal distance within SAMS areas. Using the default of one to capture that plants cluster tightly together, we find that a $10 \%$ increase in external offshoring translates into a higher probability of job separation of $0.06 \%$, while the same figure using a withinSAMS area distance based on the circle radius is as high as $4.4 \%$. As before, these effects are reduced by higher education, youth, and being newly employed.

Another concern is our mixed results for the impact of education when exposed to offshoring. As argued by Blinder (2006), there may not be a clear correlation between the education required for a particular job and the job's vulnerability to offshoring, as offshorable jobs can be found at all skill levels. Instead of education, we therefore make use of Blinder's (2009) index of the offshorability of the worker's occupation. ${ }^{37}$ The results for offshorability, separate or interacted with internal or external offshoring, are

\footnotetext{
37 Notice that our data on individuals also includes information on occupation.
} 
insignificant, while the other interactions as well as the level effect of external offshoring are unchanged.

In addition, we have reduced and altered the interaction terms with offshoring, and our results are robust to these changes. For example, dropping the interaction between external offshoring and the cohort and/or the spell dummy gives us similar results (i.e., an increased probability of exiting due to external offshoring is reduced by a higher education). Changing the spell dummy interacted with external offshoring to the first or the first 5 years provides similar results as before, although the magnitude of the interaction term increases in the first change while decreasing in the second (with coefficients of -0.015 and -0.008 ). Hence, our results presented above are in the intermediate range. We have also altered our cohort interaction term by including the third cohort, which gives equivalent results as above. On the other hand, changing the perspective by interacting with a dummy for the oldest cohort (older than 50), instead of the two or three youngest, shifts the interaction term from negative to positive. That is, external offshoring increases the probability of a job exit for workers over 50 .

Finally,Table 8 in the Appendix shows the result of our base regression (column 4 in Table 1) of external offshoring on non-offshoring firms using an alternative instrument and an ordinary least square regression. The alternative instrument excludes neighboring countries such as Finland, Norway, Denmark, and Germany to minimize the risk of an instrument influenced by similar demand shocks as in Sweden. The results from using the two different instruments are however very similar. In addition, the results based on an ordinary least square have the same sign and a similar magnitude as our IV coefficients, which adds support to our instrumental approach.

\section{Conclusion}

The effect of offshoring on labor markets may be ambiguous since offshoring competes directly with domestic workers producing the same input on one hand, while it may boost the output of firms engaged in offshoring on the other hand. This ambiguity has prompted a large empirical literature, and several studies find support for heterogeneous effects of offshoring on workers when it comes to their skills (e.g., based on educational level, age, or worker experience). However, few studies have been able to study these effects at the firm level with the help of employee-employer linked information, and none has tried to capture the broader picture by investigating how a firm's offshoring influences downstream firms in their proximity due to the local nature of markets. This is what we call external offshoring. Using matched employeremployee data from Sweden, we investigate the effects of offshoring on workers' job security. Our focus is on the external offshoring (i.e., neighboring firms' offshoring activities) effects on workers' employment. Another focal point of this study concerns the effects on workers in small and medium-sized firms (SMEs). Although these firms are less likely to offshore themselves, their dependency on the local market may make them disproportionately more affected by offshoring decisions made by other firms, an issue so far ignored in previous studies. Simultaneously, we address the potential endogeneity of offshoring with the help of an instrument based on world supply shocks to reach a causal interpretation of the effects of offshoring on workers' job separation.

One of our main results is that external offshoring has a significant impact on job separation (insecurity), and that its inclusion even removes the impact of internal offshoring. Moreover, the increased risk of a job exit from external offshoring is limited to workers in SMEs that do not offshore themselves. This result is indicative of local markets being more important for smaller firms, making these firms more vulnerable to shocks caused by offshoring carried out in the vicinity. The result also relates to the notion that small firms contribute disproportionately to job creation and job destruction (see, e.g., Hijzen et al., 2010, and ILO, 2019). Here, with respect to the effects of external offshoring, we find that the destructive part (i.e., the increased number of job exits) seems to be biased towards removing old jobs in SMEs, since having a university degree, being young, and being new to the job reduce the probability of a job separation. This is suggestive of a Schumpeterian destructive creation mechanism, where offshoring destroys old jobs (of typically low-skilled older workers) while creating new jobs (for younger high-skilled workers). Although this might be an overall beneficial process, the adjustment cost for the individual of a job exit may be considerable. While Sweden is known for its robust safety net that insulates workers from the worst effects of unemployment, Swedish policy makers could address unemployment due to external offshoring by working with SMEs to address the risk of depending too much on the local market and supplying to a limited number of firms in Sweden. 
SMEs that sell intermediate goods to other firms should be encouraged to expand and diversify their customer base both locally and internationally (through export) to reduce the negative effects of external offshoring on their activities and workforce. Future research should shed light on the type of job exits — exit to a new job or to unemployment - that external offshoring brings about and in the case of an exit to a new job, the type of firms where the new job is found.

\section{Appendix}

Table 5 Distribution of survivals and exits by job duration

\begin{tabular}{|c|c|c|c|c|c|}
\hline \multirow[t]{2}{*}{ Length of duration } & \multirow{2}{*}{$\begin{array}{l}\text { No of } \\
\text { Survivals }\end{array}$} & \multirow{2}{*}{$\begin{array}{l}\text { Distribution of } \\
\text { Exits }\end{array}$} & \multicolumn{3}{|c|}{ Percentage of exits after duration } \\
\hline & & & Survivals & Exits & \\
\hline 1 & 465,881 & 157,083 & 22.01 & 46.60 & 25.22 \\
\hline 2 & 343,006 & 66,813 & 16.20 & 19.82 & 16.30 \\
\hline 3 & 270,511 & 37,412 & 12.78 & 11.10 & 12.15 \\
\hline 4 & 229,032 & 23,409 & 10.82 & 6.95 & 9.27 \\
\hline 5 & 184,370 & 15,835 & 8.71 & 4.70 & 7.91 \\
\hline 6 & 147,405 & 11,581 & 6.96 & 3.44 & 7.28 \\
\hline 7 & 119,475 & 8288 & 5.64 & 2.46 & 6.49 \\
\hline 8 & 98,573 & 6148 & 4.66 & 1.82 & 5.87 \\
\hline 9 & 80,163 & 4375 & 3.79 & 1.30 & 5.18 \\
\hline 10 & 64,405 & 2935 & 3.04 & 0.87 & 4.36 \\
\hline 11 & 49,477 & 1845 & 2.34 & 0.55 & 3.59 \\
\hline 12 & 35,708 & 893 & 1.69 & 0.26 & 2.44 \\
\hline 13 & 20,365 & 436 & 0.96 & 0.13 & 2.10 \\
\hline 14 & 8540 & 0 & 0.40 & 0 & 0 \\
\hline
\end{tabular}

Table 6 Covariates

\begin{tabular}{|c|c|c|c|}
\hline Variable & Definition & Mean & Min/Max \\
\hline Spell event & $\begin{array}{l}\text { Takes the value of } 1 \text { at the last year of an } \\
\text { employer-employee match (based on the worker's } \\
\text { major source of income) at plant level, } 0 \text { other- } \\
\text { wise }\end{array}$ & 0.13 & $0 / 1$ \\
\hline \multicolumn{4}{|l|}{ Offshoring variables } \\
\hline \multicolumn{4}{|l|}{ Firm level: } \\
\hline (Internal) offshoring & $\begin{array}{l}\text { Firm level imports of processed intermediate } \\
\text { goods. } \mathrm{E}+9 \mathrm{SEK}\end{array}$ & 1.71 & $0 / 24.8$ \\
\hline Imports & Total firm level imports. E+9 SEK & 2.53 & $0 / 76.4$ \\
\hline (Internal) offshoring narrow & $\begin{array}{l}\text { Firm level imports of processed intermediate } \\
\text { goods belonging to the firm's 3-digit industry } \\
\text { code. } E+9 \text { SEK }\end{array}$ & 1.70 & $0 / 24.7$ \\
\hline \multicolumn{4}{|l|}{ Regional level: } \\
\hline External offshoring & $\begin{array}{l}\text { Weighted sum at SAMS level of all regions' } \\
\text { offshoring (using spatial weights such as inverted } \\
\text { distance, squared-inverted distance, and SAMS } \\
\text { regions within a range). See definition in the text. } \\
\text { E+7 SEK }\end{array}$ & 2.38 & $0.18 / 28.4$ \\
\hline
\end{tabular}


Table 6 (continued)

\begin{tabular}{|c|c|c|c|}
\hline Variable & Definition & Mean & Min/Max \\
\hline \multicolumn{4}{|l|}{ Individual characteristics } \\
\hline High-skilled & $\begin{array}{l}\text { Long education defined by the SUN } 2000 \text { category } \\
6 \text {, which implies a university education of three } \\
\text { years or more }\end{array}$ & 0.21 & $0 / 1$ \\
\hline Income & $\begin{array}{l}\text { Income from salary and/or own business. } 1000 \\
\text { SEK. Note that minimum and maximum values } \\
\text { are based on the percentiles ( } 1 \% \text { and } 99 \% \text { ) in } \\
\text { order to exclude outliers }\end{array}$ & 296 & $28 / 902$ \\
\hline Number of jobs & $\begin{array}{l}\text { Number of unique employer-employee matches } \\
\text { since } 1997 \text { (including } 1997 \text { and 2011) }\end{array}$ & 3.40 & $1 / 15$ \\
\hline Female & Gender variable & & $0 / 1$ \\
\hline Swedish & Swedish nationality & 0.94 & $0 / 1$ \\
\hline Family & Family with children & 0.58 & $0 / 1$ \\
\hline Cohort $(<30)$ & Younger than 30 & 0.26 & $0 / 1$ \\
\hline Cohort (30-39) & Between the age of 30 and 40 & 0.30 & $0 / 1$ \\
\hline Cohort (40-49) & Between the age of 40 and 50 & 0.24 & $0 / 1$ \\
\hline Cohort $(>49)$ & Older than 50 & 0.19 & $0 / 1$ \\
\hline \multicolumn{4}{|l|}{ Firm characteristics } \\
\hline TFP & $\begin{array}{l}\text { Total Factor Productivity, defined as in Olley and } \\
\text { Pakes (1996) }\end{array}$ & 14.42 & $0.9 / 23.9$ \\
\hline Capital intensity & $\begin{array}{l}\text { The deflated value of total assets (using producer } \\
\text { price index at 3-digit level and } 1997 \text { as base year) } \\
\text { per employee. 1000 SEK }\end{array}$ & 947 & $1.7 / 1540 \mathrm{E}+6$ \\
\hline \multicolumn{4}{|l|}{ Plant characteristics } \\
\hline Workforce & Number of employees & 942 & $1 / 13541$ \\
\hline Comparing characteristics in 2011 (* indicates a sig & nificant difference) & Offshoring & No offshoring \\
\hline \multicolumn{4}{|l|}{ Individual characteristics } \\
\hline Number of workers & & 222,477 & 55,142 \\
\hline Age of workers* & & 40 & 41 \\
\hline Income (million SEK)* & & 0.37 & 0.28 \\
\hline \multicolumn{4}{|l|}{ Plant characteristics } \\
\hline Number of plants & & 6280 & 12,711 \\
\hline Number of workers per plant* & & 61 & 7 \\
\hline Share of workers defined as white collar* & & 0.38 & 0.35 \\
\hline \multicolumn{4}{|l|}{ Firm characteristics } \\
\hline Number of firms & & 4676 & 12,502 \\
\hline Small and Medium Sized firms (less than 250 emplc & yees)* & 4430 & 12,498 \\
\hline Firm sales (million SEK)* & & 325 & 10 \\
\hline Labor productivity (million SEK sales per labor)* & & 2.4 & 0.98 \\
\hline
\end{tabular}


Table 7 First-stage regressions

\begin{tabular}{|c|c|c|c|c|}
\hline \multirow{2}{*}{ Variable } & \multicolumn{4}{|c|}{ Table 1 Column (2) } \\
\hline & Ln (offshoring) & $\begin{array}{l}\text { Ln (offshoring) } \\
\text { x high skilled }\end{array}$ & $\begin{array}{l}\text { Ln (offshoring) } \\
\text { x young worker }\end{array}$ & $\begin{array}{l}\text { Ln (offshor- } \\
\text { ing) x new } \\
\text { worker }\end{array}$ \\
\hline \multicolumn{5}{|l|}{ Instrument offshoring } \\
\hline Ln (MIV) & $\begin{array}{l}0.181 * * * \\
(0.000)\end{array}$ & $\begin{array}{l}-0.027^{* * *} \\
(0.000)\end{array}$ & $\begin{array}{l}0.012 * \\
(0.096)\end{array}$ & $\begin{array}{l}-0.387 * * * \\
(0.000)\end{array}$ \\
\hline \multicolumn{5}{|l|}{ Interactions } \\
\hline High skilled × Ln (MIV) & $\begin{array}{l}-0.004 * * * \\
(0.000)\end{array}$ & $\begin{array}{l}0.168 * * * \\
(0.000)\end{array}$ & $\begin{array}{l}0.035 * * * \\
(0.000)\end{array}$ & $\begin{array}{l}0.001 \\
(0.579)\end{array}$ \\
\hline Young worker $\times$ Ln $($ MIV $)$ & $\begin{array}{l}-0.001 * * * \\
(0.000)\end{array}$ & $\begin{array}{l}0.000 \\
(0.123)\end{array}$ & $\begin{array}{l}0.010 * * * \\
(0.000)\end{array}$ & $\begin{array}{l}0.002 * * * \\
(0.000)\end{array}$ \\
\hline New worker $\times$ Ln $($ MIV) & $\begin{array}{l}0.002 \\
(0.583)\end{array}$ & $\begin{array}{l}0.030 * * * \\
(0.000)\end{array}$ & $\begin{array}{l}0.064 \\
(0.000)\end{array}$ & $\begin{array}{l}0.835 * * * \\
(0.000)\end{array}$ \\
\hline Observations & $1,643,788$ & $1,643,788$ & $1,643,788$ & $1,643,788$ \\
\hline$R$-squared & 0.965 & 0.984 & 0.978 & 0.983 \\
\hline F statistics for instruments & 130.45 & 40.31 & 243.53 & 290.52 \\
\hline
\end{tabular}

Only the results for the offshoring instrument and its interactions are reported. The regressions include all other worker and firm controls as in Table 1. All regressions include plant, municipality-year, and spell duration fixed effects. Robust $p$-values (in parentheses) based on standard errors clustered at SAMS-year level. $* * *, * *$, and $*$ denote significance at the 1,5 , and $10 \%$ level, respectively.

Table 8 External offshoring and alternative instrument

\begin{tabular}{|c|c|c|c|}
\hline Variable & (1) IV base & (2) IV altern & (3) OLS \\
\hline \multicolumn{4}{|l|}{ Worker level } \\
\hline High-skilled & $\begin{array}{l}0.164 * * * \\
(0.001)\end{array}$ & $\begin{array}{l}0.241 * * * \\
(0.000)\end{array}$ & $\begin{array}{l}0.052 \\
(0.120)\end{array}$ \\
\hline Ln (income) & $\begin{array}{l}-0.039 * * * \\
(0.000)\end{array}$ & $\begin{array}{l}-0.043^{* * *} \\
(0.000)\end{array}$ & $\begin{array}{l}-0.039 * * * \\
(0.000)\end{array}$ \\
\hline Ln (number of jobs) & $\begin{array}{l}0.035 * * * \\
(0.000)\end{array}$ & $\begin{array}{l}0.035 * * * \\
(0.000)\end{array}$ & $\begin{array}{l}0.035 * * * \\
(0.000)\end{array}$ \\
\hline Female & $\begin{array}{l}-0.011 * * * \\
(0.066)\end{array}$ & $\begin{array}{l}-0.013 * * * \\
(0.000)\end{array}$ & $\begin{array}{l}-0.011^{* * *} \\
(0.00)\end{array}$ \\
\hline Swedish & $\begin{array}{l}0.022 * * * \\
(0.000)\end{array}$ & $\begin{array}{l}0.022 * * * \\
(0.000)\end{array}$ & $\begin{array}{l}0.022 * * * \\
(0.000)\end{array}$ \\
\hline Family & $\begin{array}{l}-0.005^{* * * *} \\
(0.000)\end{array}$ & $\begin{array}{l}-0.006^{* * * *} \\
(0.000)\end{array}$ & $\begin{array}{l}-0.005^{* * * *} \\
(0.000)\end{array}$ \\
\hline \multicolumn{4}{|l|}{ Firm/plant level } \\
\hline Ln (TFP) & $\begin{array}{l}0.004 * * \\
(0.032)\end{array}$ & $\begin{array}{l}0.004 * * \\
(0.020)\end{array}$ & $\begin{array}{l}0.003 * * \\
(0.045)\end{array}$ \\
\hline Ln (capital intensity) & $\begin{array}{l}-0.007 * * * \\
(0.007)\end{array}$ & $\begin{array}{l}-0.006^{* *} \\
(0.020)\end{array}$ & $\begin{array}{l}-0.007 * * * \\
(0.006)\end{array}$ \\
\hline Ln (workforce(plant)) & $\begin{array}{l}0.060 * * * \\
(0.000)\end{array}$ & $\begin{array}{l}0.060 * * * \\
(0.000)\end{array}$ & $\begin{array}{l}0.061 * * * \\
(0.000)\end{array}$ \\
\hline
\end{tabular}

Regional level 
Table 8 (continued)

\begin{tabular}{llll}
\hline Variable & $(1)$ IV base & (2) IV altern & $(3)$ OLS \\
\hline Ln (external offshoring) & $0.024^{* *}$ & $0.019^{*}$ & $(0.085)$ \\
& $(0.018)$ & & $(0.000)$ \\
Regional level: & & $-0.011^{* * *}$ & -0.002 \\
High-skilled $\times$ Ln (external offshoring) & $-0.007 * * *$ & $(0.001)$ & $(0.268)$ \\
& $(0.003)$ & $-0.011^{* * *}$ & -0.001 \\
Young worker $\times$ Ln (external offshoring) & $-0.003 * *$ & $(0.000)$ & $(0.139)$ \\
& $(0.040)$ & $0.024 * * *$ & $-0.004 * * *$ \\
New worker $\times$ Ln (external offshoring) & $-0.011^{* * *}$ & $(0.000)$ & $(0.000)$ \\
Observations & $(0.000)$ & 550,549 & 550,549 \\
$R$-squared & 550,549 & 0.200 & 0.174 \\
Kleiberger-Paap F stat & 0.205 & 62.77 &
\end{tabular}

All regressions include plant, municipality-year, and spell duration fixed effects. Cohort age group dummies are also included. Robust $p$-values (in parentheses) are based on standard errors clustered at SAMS-year level. ***,**, and * denote statistical significance at the 1, 5, and 10\% significance levels, respectively. Column 1 shows the results from our base regression in Table 1 while the alternative instrument used in column 1 excludes neighboring countries such as Finland, Norway, Denmark, and Germany.

Acknowledgements We would like to thank Professor Beata Javorcik and seminar participants at Lund University and Örebro University. We are also grateful to the conference participants at DIEW in Aarhus, 2016, DEGIT XXI conference in Nottingham, 2016, ETSG in Helsinki, 2016, and ADI conference in Copenhagen, 2017, for valuable comments and suggestions.

Funding Financial support from the Torsten Söderberg's Foundation and the Jan Wallander and Tom Hedelius Foundation is gratefully acknowledged.

\section{References}

Acemoglu, D., Carvalho, V. M., Ozdaglar, A., \& TahbazSalehi, A. (2012). The network origins of aggregate fluctuations. Econometrica, 80(5), 1977-2016. https://doi.org/ 10.3982/ECTA9623

Amemiya, T. (1999). A note on left censoring. In C. Hsiao, K. Lahiri, L.-F. Lee, \& M. H. Pesaran (Eds.), Analysis of panels and limited dependent variable models (pp. 7-22). Cambridge University Press.

Amiti, M., \& Davis, D. R. (2013). Trade, firms and wages: Theory and evidence. Review of Economic Studies, 79, 1-36. https://doi.org/10.1093/restud/rdr016

Andersson, L., Karpaty, P., \& Savsin, S. (2016). Firm-level effects of offshoring of materials and services on relative labor demand. Review of World Economics, 152(2), 321350. https://doi.org/10.1007/s10290-015-0243-8

Andersson, L., Karpaty, P., \& Savsin, S. (2017). Labour demand, offshoring and inshoring: Evidence from Swedish firm-level data. World Economy, 40(2), 240-274. https://doi.org/10.1111/twec.12396
Angrist, J., \& Pischke, J.-S. (2008). Mostly harmless econometrics. Princeton University Press.

Arnarson, B., and Gullstrand, J., 2016. Linking services to manufacturing exports. Scandinavian Working Papers in Economics No. 2016:27, Lund University.

Autor, D.H., Dorn, D., and Hanson, G.H., 2013. The China syndrome: Local labor market effects of import competition in the United States. American Economic Review, 103(): 2121-2168. https://www.jstor.org/stable/42920646

Autor, D.H., Dorn, D., Hanson, G.H., and Song, J., 2014. Trade adjustment: Worker-level evidence. Quarterly Journal of Economics, 129(): 1799-1860. https://doi.org/10.1093/ qje/qju026

Becker, S. O., Ekholm, K., \& Muendler, M.-A. (2013). Offshoring and the onshore composition of tasks and skills. Journal of Internatonal Economics, 90(1), 91-106. https://doi.org/10.1016/j.jinteco.2012.10.005

Bennett, R., Bratton, W., \& Robson, P. (2000). Business advice: The influence of distance. Regional Studies, 34(9), 813-828. https://doi.org/10.1080/00343400020002958

Bernard, A., Moxnes, A., \& Saito, Y. U. (2019). Production networks, geography and firm performance. Journal of Political Economy, 127(2), 639-688. https://doi.org/10. 1086/700764

Blinder, A.S., 2006. Offshoring: The Next industrial revolution? Foreign affairs, March/April 2006, pp. 113-128. https://www.foreignaffairs.com/articles/2006-03-01/offsh oring-next-industrial-revolution

Blinder, A.S., 2009. How many US jobs might be offshorable? World Economics, 10 (2): 41-78. https://www.worldeconomics-journal.com/ArticleDetails.details?ID $=376$

Botero, J. C., Djankov, S., La Porta, R., Lopez-de-Silanes, F., \& Shleifer, A. (2004). The regulation of labor. The Quarterly Journal of Economics, 119(4), 1339-1382. https:// doi.org/10.1162/0033553042476215 
Castellani, D., Mariotti, I., \& Piscitello, L. (2008). The impact of outward investments on parent company's employment and skill composition. Structural Change and Economic Dynamics, 19(1), 81-94. https://doi.org/10.1016/j.strueco. 2007.11.006

Couch, K. A., \& Placzek, D. W. (2010). Earnings losses of displaced workers revisited. The American Economic Review, 100(1), 572-589. https://doi.org/10.1257/aer. 100.1.572

Davidson, C., and Matusz, S.J., 2011. Trade and labour markets. In Bernhofen, D., Falvey, R., Greenaway, D., and Kreickemeier, U., (eds.), Palgrave Handbook of International Trade. Palgrave MacMillan, Hampshire, pp. 391422. https://doi.org/10.1007/978-0-230-30531-1_14

Egger, H., \& Egger, P. (2005). Labor market effects of outsourcing under industrial interdependence. International Review of Economics and Finance, 14(3), 349-363. https://doi.org/10.1016/j.iref.2004.12.006

Egger, H., Pfaffermayr, M., \& Weber, A. (2007). Sectoral adjustment of employment to shifts in outsourcing and trade: Evidence from a dynamic multinomial logit model. Journal of Applied Econometrics, 22, 559-580. https:// doi.org/10.1002/jae.914

Eliason, M., \& Storre, D. (2006). Lasting or latent scars? Swedish evidence on the long-term effects of job displacement. Journal of Labor Economics, 24(4), 831-856. https://doi. org/10.1086/506487

Feenstra, R.C., and Hanson, G.H., 1996. Globalization, outsourcing and wage inequality. American Economic Review, 86(2): 240-245. https://www.jstor.org/stable/2118130

Feenstra, R. C., \& Hanson, G. H. (1997). Foreign direct investment and relative wages: Evidence from Mexico's maquiladoras. Journal of International Economics, 42(3-4), 371-393. https://doi.org/10.1016/S0022-1996(96)01475-4

Feenstra, R. C., \& Hanson, G. H. (1999). The impact of outsourcing and high-technology capital on wages: Estimates for the United States, 1979-1990. Quarterly Journal of Economics, 114(3), 907-940. https://doi.org/10.1162/ 003355399556179

Furusawa, T., Ito, K., Inui, T., and Tang, H., 2015. Offshoring, relationship-specificity, and domestic production networks. RIETI Discussion Paper Series 15-E-122. https:// www.rieti.go.jp/jp/publications/dp/15e122.pdf

Geishecker, I., Riedl, M., Frijters P. (2012). Offshoring and job loss fears: An econometric analysis of individual perceptions, Labour Economics, 19(5):738-747. https://doi.org/ 10.1016/j.labeco.2012.05.018

Grossman, G. M., \& Rossi-Hansberg, E. (2008). Trading tasks: A simple theory of offshoring. American Economic Review, 98(5), 1978-1997. https://doi.org/10.1257/aer. 98.5.1978

Growth Analysis, 2014. Sweden in global value chains-Changing roles of firms in an increasingly globalized economy, Report 2014:12. URL: https://www.tillvaxtanalys.se/inenglish/publications/reports/reports/2014-12-16-swedenin-global-value-chains-----changing-roles-of-firms-in-anincreasingly-globalized-economy.html

Gullstrand, J., 2017. The features of a survey on the export decisions of Swedish small and medium-sized enterprises. Scandinavian Working Papers in Economics No. 2017:6, Lund University.
Gullstrand, J., \& Tezic, K. (2008). Who leaves after entering the primary sector? Evidence from Swedish micro-level data. European Review of Agricultural Economics, 35(1), 1-28. https://doi.org/10.1093/erae/jbn009

Görg, H., \& Görlich, D. (2015). Offshoring, wages and job security of temporary workers. Review of World Economy, 151(3), 533-554. https://doi.org/10.1007/ s10290-015-0220-2

Head, K., and Mayer, T., 2004. The empirics of agglomeration and trade. In Henderson, V, and Thisse, J.-F. (eds), Handbook of Regional and Urban Economics Volume 4. Elsevier, pp. 2609-2669. https://doi.org/10.1016/S15740080(04)80016-6

Helpman, E. (2006). Trade, FDI, and the organization of firms. Journal of Economic Literature, 44(3), 589-630. https:// doi.org/10.1257/jel.44.3.589

Hess, W., and Persson, M., 2012. Exploring the duration of EU imports. Review of World Economics, 147(4): 10831107. https://www.jstor.org/stable/30032346

Hijzen, A., Upward, R., \& Wright, P. W. (2010). Job creation, job destruction and the role of small firms: Firm-level evidence for the UK. Oxford Bulletin of Economics and Statistics, 72(5), 621-647. https://doi.org/10.1111/j.14680084.2010.00584.X

Hillberry, R., \& Hummels, D. (2008). Trade responses to geographic frictions: A decomposition using micro-data. European Economic Review, 52(3), 527-550. https://doi. org/10.1016/j.euroecorev.2007.03.003

Hsieh, C.-T., \& Woo, K. T. (2005). The impact of outsourcing to China on Hong Kong's labor market. American Economic Review, 95(5), 1673-1687. https://doi.org/10.1257/ 000282805775014272

Hummels, D. (2007). Transportation costs and international trade in the second era of globalization. Journal of Economic Perspectives, 21(3), 131-154. https://doi.org/10. 1257/jep.21.3.131

Hummels, D., Jørgensen, R., Munch, J., \& Xiang, C. (2014). The wage effects of offshoring: Evidence from danish matched worker-firm data. American Economic Review, 104(6), 1597-1629. https://doi.org/10.1257/aer.104.6.1597

Hummels, D., Munch, J. R., \& Xiang, C. (2018). Offshoring and labor markets. Journal of Economic Literature, 56(3), 981-1028. https://doi.org/10.1257/jel.20161150

Huttunen, K., Moen, J., \& Salvanes, K. (2011). How destructive is creative destruction? Effects of job loss on job mobility, withdrawal and income. Journal of the European Association, 9(5), 840-870. https://doi.org/10. 1111/j.1542-4774.2011.01027.x

Hummels, D., and Schaur, G., 2013. Time as a trade barrier. American Economic Review, 103(7): 2935-2959. https:// www.jstor.org/stable/42920676

International Labour Organization (ILO), 2019. Small matters: Global evidence on the contribution to employment by the self-employed, micro-enterprises and SMEs. ISBN: 9789221339915

Jacobson, L.S., LaLonde, R.J., and Sullivan, D.G., 1993. Earnings losses of displaced workers. American Economic Review, 83(4): 685-709. https://www.jstor.org/stable/ 2117574

Jenkins, S. P. (1995). Easy estimation methods for discretetime duration models. Oxford Bulletin of Economics and 
Statistics, 57(1), 129-138. https://doi.org/10.1111/j.14680084.1995.tb00031.x

Keller, W., \& Yeaple, S. R. (2013). The gravity of knowledge. American Economic Review, 103(4), 1414-1444. https:// doi.org/10.1257/aer.103.4.1414

Martins, P.S., and Opromolla,L.D., 2009. Exports, imports and wages: Evidence from matched firm-worker-product panels. IZA Discussion Paper 4646.

Merlevede, B., \& Michel, B. (2020). Downstream offshoring and firm-level employment. Canadian Journal of Economics/revue Canadienne D'économique, 53(1), 249283. https://doi.org/10.1111/caje.12425

Mion, G., \& Zhu, L. (2013). Import competition from and offshoring to China: A curse or blessing for firms? Journal of International Economics, 89(1), 202-215. https://doi.org/ 10.1016/j.jinteco.2012.06.004

Moretti, E. (2010). Local multipliers. American Economic Review, 100(2), 373-377. https://doi.org/10.1257/aer. 100.2.373

Munch, J. R. (2010). Whose job goes abroad? International outsourcing and individual job separations. Scandinavian Journal of Economics, 112(2), 339-360. https://doi.org/ 10.1111/j.1467-9442.2010.01607.x

Nilsson Hakkala, K., Heyman, F., \& Sjöholm, F. (2014). Multinational firms, acquisitions and job tasks. European
Economic Review, 66, 248-265. https://doi.org/10.1016/j. euroecorev.2013.12.003

Nilsson Hakkala, K., and Huttunen, K., 2016. Worker-level consequences of import shocks. IZA Discussion Paper 10033.

OECD Employment Outlook 2013. OECD Publishing, Paris

OECD Employment Outlook 2015. OECD Publishing, Paris

Olley, S. G., \& Pakes, A. (1996). The dynamics of productivity in the telecommunications equipment industry. Econometrica, 64(4), 1263-1297. https://doi.org/10.2307/2171831

Svalund, J., Bergström Casinowsky, G., Dölvik, J. E., Håkansson, K., Jarvensivu, A., Kervinen, H., Juul Möberg, R., \& Piiranen, T. (2013). Stress testing the Nordic models: Manufacturing labour adjustment during crisis. European Journal of Industrial Relations., 19(3), 183-200. https:// doi.org/10.2307/2171831

Wooldridge, J. M. (2010). Econometric analysis of cross section and panel data (2nd edition). MIT Press.

Wrona, J. (2015). Border effects without borders: What divides Japan's internal trade? International Economic Review, 59, 1209-1262. https://doi.org/10.1111/iere.12302

Publisher's note Springer Nature remains neutral with regard to jurisdictional claims in published maps and institutional affiliations. 